\title{
The Determinants of Debt Load for Companies in Emerging Markets
}

\author{
Mark Klestov $₫$ \\ Analyst, Baring Vostok Capital Partners, Moscow, Russia, \\ markklest@gmail.com, $\underline{\text { ORCID }}$
}

\section{Irena Jindřichovská}

Doctor of Economics, Professor, Department of Financial Management, Metropolitan University Prague, Czech Republic, irena.jindrichovska@mup.cz, $\underline{\text { ORCID }}$

\section{Abstract}

Corporate capital structure is one of the key elements of long-term development, which determines the company value. Consequently, defining the factors that influence the debt load level of a company and, hence, its capital structure is also of great importance.

In this paper we have collected a sample of data of 753 Russian companies and 292 Brazilian companies for 2020 to evaluate the influence of various factors on their debt-load level. The data was downloaded from Bloomberg database and the basis of the analysis focuses on evaluation of conventional academic theories on capital structure, and a regression analysis based on variables extracted from a set of original hypotheses.

Among our results, our analysis illustrates that individual sets of determinants differ significantly in explanatory power, and operate unequally when contrasting Russian companies and Brazilian ones. Additionally, it was established that when companies define their debt load, they do not limit themselves to a single theory of capital structure. We conclude, inter alia, that it is impossible to identify with confidence which of the examined theories companies are most likely to follow in their actions, because observed interrelations between relevant variables and debt load have indications of various academic theories.

Keywords: capital structure, debt financing, debt load, theories of capital structure, profitability, growth opportunities, company size, tangibility, level of company liquidity, rate of return (or discount rate), corporate economic efficiency For citation: Klestov, M. and Jindřichovská, I. (2021) “The Determinants of Debt Load for Companies in Emerging Markets", Journal of Corporate Finance Research | ISSN: 2073-0438, 15(3), pp. 39-59. doi: 10.17323/j.jcfr.20730438.15.3.2021.39-59. 


\section{Introduction}

In the current circumstances of ever-rising competition, a company's long-term development is inextricably entwined with its efficiency in all economic sectors. Defining the debt load level (and capital structure in general) represented by bond-secured loans and credit funds is one of the key strategic points of this development. Where the debt-load is at an appropriate level, a company minimizes its risk of financial imbalance, which, in turn, enables its market value to rise. Conversely, the incorrect definition of a debt-load level may bring about the loss of a company's competitive advantages, decrease its market value, and/or initiate agency conflicts between company shareholders and managers.

The sustainable long-run development of a company is closely linked with the definition of its capital structure, including the level of its debt financing applying various instruments. Raising debt is a very important development factor because it allows the use of proceeds for investment in the phase of expansion of production capacity. However, an increase in debt load may result in negative consequences and contribute to company bankruptcy.

In recent decades, emerging markets have been growing faster, due to development of industrial production, which has required, among other things, serious financial investments. Nevertheless, industry-based growth is gradually slowing. This means that in an ever-changing environment, companies in these markets need competent debtload management and an ability to define its determinants in order to maintain their previous growth rates.

The main criteria for selection of companies for this research comprise corporate shares or bonds in circulation in national stock exchanges, as well as companies' affiliations with developed markets. The two samples used consist of 753 Russian and 292 Brazilian companies from the year 2020 .

This research may assist shareholders and managers of companies in defining the policy of debt financing in companies (subject to business geography). This research may also be of interest to financial organizations and consulting agencies which render services related to debt-load management.

\section{Explanations of Debt Load Determinants}

In the current environment of constantly-growing competition, economic uncertainty, and (particularly in Russia) possible sanction pressures, companies try to obtain as many competitive advantages as possible in order to maintain business growth. The ability to create and use these advantages is directly associated with the opportunity to invest in the development of key business areas. Such investments may be related to modernization of production processes, a study of new technologies and R\&D applications, expansion due to horizontal and vertical mergers and acquisitions, etc. Significant cash infusions are necessary to implement such projects. As an example we can see that capital investments of the Mining and Metallurgical Company Norilsk Nickel in 2020 amounted to RUB 123.3 billion[1], while capital investments of PAO Novatek increased to RUB 204.6 billion (the largest amount in the past five years)[2].

Similarly, capital investments of the mining and metallurgical company Norilsk Nickel in 2020 amounted to RUB 123.3 billion $^{2}$ while capital investments of PAO Novatek equalled RUB 204.6 billion (the largest amount in the recent five years) ${ }^{3}$.

Various instruments are applied to finance the increasing demands of the company, such as financing employing equity capital or raising debt (loan) capital. We may observe that the smaller the cost of raising any debt capital for a company, the bigger its resulting advantage over competitors due to its ability to raise large amounts of financing at a lower cost, to have a reserve for its products' price reduction with lower funding costs, and to have more competitive advantages.

Debt capital is the cheapest of the above-mentioned capital sources. It consists of bond-secured loans or bank loans. However, in case of a serious growth of corporate debt load this type of capital will be more and more expensive and the company's inability to service its debt may result in bankruptcy. Debt load is directly related to corporate capital structure. Therefore, it is important when analysing debt load to take into consideration corporate capital structure in general, i.e., the equity to debt ratio, when defining corporate debt load.

The essential difference between the above types of capital consists of cash flows used to pay for them. While payments for debt capital are defined beforehand, payments for equity capital are made with whatever funds remain after repayment of obligations to all other stakeholders. Besides, in the case of company liquidation, debt investors will be the first ones to be paid. Precisely due to these factors, debt financing is usually less costly than financing using equity capital. However, in the case of debt finacning investors cannot influence company management, while equity capital owners usually have such rights.

It should be noted that these types of financing are represented by external sources. As a corollary to this, we should note the potential zero-debt phenomenon that arises when companies, in general, do not strive to raise external sources and use cash flows generated by their current assets for financing.

\footnotetext{
${ }^{1}$ Kommersant. Dead-End Development Route. URL: https://www.kommersant.ru/doc/3533278 (application date: 25.02.2021).

${ }^{2}$ Nornickel. Financial Reports. URL: https://www.nornickel.ru/investors/disclosure/financials/\#2020 (application date: 25.02.2021).

${ }^{3}$ Novatek. Investors Relations. URL: https://www.novatek.ru/ru/investors/disclosure/ifrsreporting/ (application date: 25.02.2021).
} 
Since debt financing and the definition of debt load determinants is of relevance to our analysis, it is necessary to indicate the main sources of corporate debt capital formation. First of all, it is necessary to define long-term and short-term funding sources. Long term funding sources comprise obligations with a due date later than one calendar year since the date of the latest corporate report. Consequently, short term funding sources include obligations with an earlier due date which is shorter than one calendar year since the date of the latest corporate reports.

A bank loan is the most common and widely used method of raising debt capital. Loans are used to finance investment development projects as well as to maintain a company's current operations. The main advantages of this instrument are its relative simplicity (standard products imply standard documentation and a well-established procedure generally precedes loan preparation) and its availability at all stages of the company life cycle.

A second common instrument for such purposes is capital-raising bonds. This instrument is less widely used because it requires more detailed accompanying documentation, it is usually public, and it imposes certain obligations related to information disclosure in order to obtain credit ratings. Of relevance to this instrument, first it should be noted that the advantage of this instrument is the opportunity to raise funds for a significantly longer period in comparison to a bank loan. Second, it should be noted that under otherwise equal conditions, for the issuer, such funding is less costly than a loan because in the case of bonds the company cooperates directly with debt investors and does not have to pay additional interest to a bank (bank margin) as in the case of a loan. Additionally, an issue with high credit ratings presents an opportunity to issue bonds not just in local but also in foreign currency. This enables a diversification of the related debt portfolio from the point of view of currency as well as from the point of view of investors.

There are also other instruments: for example, the leasing of an asset for a certain period for certain regular payments, and hybrid financing forms which combine debt and equity capital features (preference shares, mezzanine loans etc.).

All the above examples of debt financing instruments show that when companies define their debt load, they may apply various methods of raising capital combining these instruments in different proportions. Ultimately, the definition of the debt load should be based on a strategy of furthering the development of the company and take into consideration its current size and the stage of its life cycle.

\section{Theoretical Framework}

Debt load is directly related to the notion of capital structure. As such, in this section of the paper, we will outline and evaluate a list of the most commonly applied academic and practically-relevant theories on capital structure. The majority of current studies are based upon the theory of capital structure by Franco Modigliani and Merton Miller (1958) [1]. In their seminal paper from 1958, the au- thors showed that a company's value would be the same irrespective of its capital structure. In their study, the authors used the assumptions of the perfect capital market, an absence of transaction and agency costs, and a risk-free and consistent debt interest rate, among other variables. Subsequently, several other theories arose in areas of related research, considering additional components of capital structure whilst removing some limitations of the traditional trade-off theory. These include the theory of the firm, the pecking order theory, and the new market timing theory.

Under the trade-off theory of capital structure (authors A. Kraus and R. Litzenberger [2]), the claim is made that even though debt financing allows corporations to use the tax shield (thus increasing the company value) one ought to take into consideration the costs of bankruptcy (financial imbalance costs). Bankruptcy costs increase with rising debt and reduce the company value. Thus, the company has to strike a compromise between costs of bankruptcy and benefits of the tax shield and seek an optimal balance between debt and equity resulting in company value maximization. These assumptions have been confirmed on repeated occasions [3-6].

In articulating the theory of the firm, a range of problems related to agency costs was considered, with particular significance arising from the influence of papers authored by $\mathrm{M}$. Jensen and W. Meckling [7], Demsetz, [8] Holmstrom and Tirole [9], and Rajan and Zingales [10]. This theory states that conflicts of interest between owners, managers and company creditors may influence corporate financial decisions. The first type of conflict (between owners/managers) is based on the premise that management may pursue interests that are different from the owners' interests, which is assumed to be the maximization of company value. The second type of conflict (with creditors) is related to creditors' unwillingness to provide funds for high-risk projects unsecured by corresponding pledges - while management or owners may face challenges in maximising company value utilising high-risk projects. This premise originates from the assumption that if a company is financed with a bank loan of a small amount, then the bank controls that company. Conversely then, when the company owes the bank a large amount of funds, the company starts to control the bank. In either event, the company incurs expenses related to solving such conflicts. The increase of the debt load may result in more clear manifestations of the second type of conflict (with creditors). As a consequence, this will cause a rise in agency costs for the company.

The pecking order theory, as postulated by Myers and Maljuf [11], Myers [12], Frank and Goyal [13] Jindřichovská, Körner [14] and Sheikh, et al. [15] assumes that when making decisions related to choice of funding sources a company will follow a certain hierarchical order of these sources. Undistributed profits (i.e. internal funds) which pose less risk are the foremost resort. If, however, a company needs external funding sources, first of all, least risky debt instruments (e.g. credits, bonds) are used, and subsequently more risky combined instruments (mezzanine, 
convertible debt) may be applied. Only at the last stage will corporate equity capital (i.e. the issuing of shares) be used to avoid loss of investment opportunities. Thus, the debt load level in this theory is indicative of the company's real need for external funding.

If management follows this theory, it strives to minimize expenditures for capital due to information asymmetry when raising external funding. Asymmetry consists in the fact that, as a rule, managers in the company have more information concerning current performance of the company, its possible growth prospects, and risks which a company may probably face. Besides this, often all information may be unavailable to other agents such as investors and creditors, i.e. to holders of equity and debt financing of the company. In the event this theory is observed in practice, in order to recompense such asymmetry and offset the risks it may entail, external users of information (i.e. investors and creditors) expect to have a bigger rate of return on their investments.

Thus, the pecking order theory assumes that if corporate operations are financed from the company's internal sources, information asymmetry is manifested to the least extent. However, in the case of external financing, this risk grows significantly and it is necessary to mitigate it by means of a higher rate of return for creditors and investors.

The market timing theory (McDonald [16], Elliott et al. [17] and Ahmadimousaabad et al. [18]) assumes that companies take a decision on procurement of funding, taking into consideration the current market value of shares. Taking into account the signaling effect, companies prefer to issue shares when they are overvalued and redeem them when they are undervalued.

This paper will empirically test the trade-off theory of capital structure in the two capital markets. In this vein, the studied hypotheses are formulated and measured in terms of contrast and comparison.

\section{Traditional Determinants of Debt Load}

A group of decisive factors which determine corporate debt load can be traced to a number of existing studies. These determinants comprise profitability, growth opportunities, firm size, and tangibility. A series of papers dedicated to the study of the influence of these factors on corporate debt load is considered below.

Profitability is one of the most frequently studied factors which directly influences the corporate capital structure and affects its debt load. This parameter indicates whether a company is able to gain profit from its operations after payment of all expenses and the income tax. Depending on the theory of capital structure applied, the relevant views on the influence of this factor on debt load may differ.

The trade-off theory of capital structure implies that the higher the company's profitability indicators, the larger amounts of debt it acquires. It is related to the fact that the company tries to maximize the benefit from the use of the tax shield because as profits grow, the taxes on the tax shield also increase. Additionally, the risk of potential bankruptcy is mitigated along with profits growth. This results in a decrease in the probability of and expenses from potential bankruptcy. A positive relation between these factors was confirmed in papers referenced at numbers [19-21] attached. Nevertheless, there is a significant number of papers that show the opposite effect, for example, the paper by La Rocca et. al referenced at [22], who use an example capital structure of 10,242 small and medium-sized Italian enterprises from 1996 to 2005. The authors identified a negative relation between profit and the debt amount of companies. The same conclusion has been made in other papers dedicated to the study of corporate capital structure in different economies [23; 24].

We suggest that the negative dependence is rather a characteristic of another theory of capital structure - the pecking order theory. As stated above, according to this theory the most preferred funding source of a company are its internal sources, i.e., undistributed profits. This implies that more profitable companies first use their own undistributed profits. This means that owing to a decrease of financing from borrowed funds, corporate debt load will reduce. Apart from the papers mentioned above, the paper by Asen et al. [25] also supports this interpretation, where the authors use as an example Nigerian companies from various economic sectors in the period of 1999 to 2018 and show that profitability indicators for such companies have negative dependence with a long-term and short-term debt.

As such, our Hypothesis No. 1 is: Profitability exerts a significant negative influence on corporate debt load in emerging markets.

The growth opportunities of a company are also related directly to its attempts to raise additional funding by means of debt obligations. As in the case of profitability, the influence of this factor on the use of debt is differently evaluated by different theories. The trade-off theory assumes a negative relation between debt and growth opportunities. This is due to the fact that companies with high growth potential usually incur greater expenses to procure debt capital [26]. Additionally, the use of internal funds is preferable from the point of view of avoidance of the agency problem and maintenance of financial flexibility for potential future investment decisions.

Other papers [e.g 27; 28] also identified this negative relation. For example, paper [30], using 2,329 Portuguese companies as an example, showed that the higher the company's growth potential was, the more its debt decreased in capital structure. A mixed relationship was found in [29], where the authors explored a sample of Czech SMEs.

However, according to the pecking order theory, dependence between the debt amount and growth opportunities shows positive dynamics. First of all, this is related to the fact that finance investments for quick-growth companies with a high potential often lack resources. For this reason, they are forced to use debt financing to use their investment opportunities. This positive dependence was shown in papers $[15 ; 28$; and 30$]$. 
Hypothesis No. 2: Growth opportunities have a significant positive influence on corporate debt load in emerging markets.

One important determinant of debt load is the company size. A study of this factor also gave controversial results. In this context, the perspective of actual influence of the company size on corporate debt depends on the theory under which it is analysed. According to the trade-off theory, dependence of these two indicators will be positive. This is explained by the fact that the bigger the company, the less it is exposed to bankruptcy and financial imbalance risks. Here the saying "too big to fail" is appropriate. Apart from that, the bigger the company, the more stable its cash flows. This is due to the diversification of these flows as the company business grows [32]. Large companies in general have easier access to financing because a wider choice of debt financing instruments is available to them than for small companies, and larger companies have a lower relative cost of financing due to reducing the risk of financial uncertainty. This point of view is confirmed by papers [21; 31; and 33].

Nevertheless, there are a lot of papers that show an inverse relationship between the company size and its debt load. This assumption of the pecking order theory states that as the company grows, it accumulates profit which then becomes a source of internal financing. Thus, as the company grows, it may rely more on undistributed profit as an investment resource. So, the company requires less external financing raised through debt instruments. A negative relation between debt load and the company size is indicated in papers $[10 ; 34]$.

Hypothesis No. 3: The company size exerts a significant negative influence on corporate debt load in emerging markets.

Tangibility is another factor studied in the trade-off theory and pecking order theory. Usually, the proportion of tangible assets in the company total assets is captured by this factor. Generally, both theories of capital structure are based on the fact that the bigger the proportion of tangible assets, the higher the companies' debt load. This dependence is explained by the fact that in order to provide debt funding, banks often require collateral. Tangible assets of the corporation can serve as appropriate collateral [35]. Consequently, the bigger the share of tangible assets, the larger guarantee a company can offer, and the larger is the credit amount the company is able to obtain at the price it can afford. A large proportion of tangible assets also reduces the risk of financial difficulties as long as these assets may be sold to reimburse for creditors' and, probably, shareholders' losses (even in the extreme case of bankruptcy). A positive dependence of the debt amount and proportion of tangible assets was documented in papers [31;36; 37].

Nevertheless, there are also many papers documenting negative dependence between the debt level and the proportion of corporate tangible assets. This stems from the fact that in the case of a large share of tangible assets in the structure, companies often rely more on seclf-financing using internal sources, and consequently the need for debt usage is lower. Negative relation was detected in papers [24;30;38].

Hypothesis No. 4: Tangibility has a significant negative influence on corporate debt load in emerging markets.

\section{Other Determinants of Debt Load}

The above-mentioned determinants of corporate debt load are most common in the studies dedicated to this topic. Nevertheless, there are other, less common, also important factors defining corporate debt load. Company liquidity is one of them. Apart from that, in this research, we offer to verify the influence of such factors as the required return (or discount rate) of a company (WACC) and corporate economic efficiency. Further, we consider these factors in detail.

The initial theory of capital structure by Modigliani and Miller (1958) implies that capital structure does not influence the company value. That is to say, the debt load level should not depend on the funds the company uses to maximize its value: either borrowed funds or its own funds. In its turn, that means that the required return of the company (which is usually expressed as the discount rate WACC) which takes into consideration corporate capital structure should not influence corporate debt load. This paper offers to study this relation in more detail and uses the company's WACC as one of the determinants which define the debt load level of the company. According to the trade-off theory change of the rate should have a significant impact on corporate debt load because it is based on creating the optimal ratio of debt to equity capital. Therefore, in accordance with the pecking order theory, this dependence should be insignificant because the company is guided by the hierarchy of funding sources rather than the optimal structure.

Hypothesis No. 5: The company discount rate exerts an insignificant influence on corporate debt load in emerging markets.

Company liquidity is another studied factor. Usually, the current ratio is the indicator of company liquidity. Liquidity is measured as a ratio of current assets to current liabilities capturing the company's ability to cover its shortterm liabilities. Consequently, the higher this indicator, the greater the company's ability to address its liabilities and other current investments. Thus, the higher this indicator, the lower the need for external debt financing. It follows from this that dependence between the liquidity level and corporate debt level is negative. This interrelation was identified and discussed in papers [26;39] and it confirms assumptions of the pecking order theory.

Nevertheless, some research indicates a positive dependence between liquidity and debt level. So, in paper [24] the authors studied Chinese companies in the period of 2006 to 2015 and found out that the higher their liquidity level the greater the debt load. The author attributes it to the fact that with a higher liquidity level the company may afford to raise larger amounts of short-term debt because the higher this indicator the less risky this loan is both for the company and its creditor. This result confirms the trade-off theory. 
Hypothesis No. 6: Liquidity has a significant negative influence on corporate debt load in emerging markets.

Another factor that may be also determining the debt load of the company is its economic efficiency. In this paper, economic efficiency is measured as an excess of the corporate return on assets (ROA) over its weighted average capital cost of capital or the appropriate discount rate WACC.

If the return on assets exceeds the cost of capital for the company, it is economically efficient. This indicates that the company uses its assets with the yield sufficient to cover procurement of the required capital. Consequently, if the return on assets does not cover the capital cost the company is not economically efficient even if it has the net profit.

According to the trade-off theory, economic efficiency will have a positive impact on debt load because the more efficiently the company uses its assets the larger debt it can afford to raise. Correspondingly, its debt load should increase as economic efficiency grows.

On the other hand, in conformity with the pecking order theory, the more efficiently the company manages its assets, the more it can rely on its internal resources when financing new projects. This means that the share of debt financing, as well as the level of debt load, will decrease as the efficiency of use of the company's own assets grows.

Hypothesis No.7: Economic efficiency has a significant negative influence on corporate debt load in emerging markets.

This section describes the main theories and empirical studies explaining corporate debt load. Apart from that, we have defined, described and explained the most decisive determinants which influence the corporate debt level. Further, these determinants are considered as factors that influence corporate debt load in emerging markets. The overview of factors relating to debt load is presented in Table 1 below.

Table 1. Influence of factors on debt load in accordance with dominant theories

\begin{tabular}{|c|c|c|}
\hline & $\begin{array}{l}\text { Trade-off } \\
\text { theory }\end{array}$ & $\begin{array}{l}\text { Pecking order } \\
\text { theory }\end{array}$ \\
\hline Profitability & Positive & Negative \\
\hline Tangibility & Positive & Positive \\
\hline Company size & Positive & Negative \\
\hline
\end{tabular}

Growth
opportunities Negative $\quad$ Positive

$\begin{array}{lll}\text { Discount rate } & \begin{array}{l}\text { Significant } \\ \text { influence }\end{array} & \begin{array}{l}\text { Insignificant } \\ \text { influence }\end{array} \\ \text { Liquidity } & \text { Positive } & \text { Negative }\end{array}$

Economic efficiency

Positive

Negative

\section{Analysis}

\section{The Theoretical Framework for the Study}

The main method of study of the influence of determinants on corporate debt load is regression analysis, which reveals the possible relations between different variables used in the model. There are two types of variables in this method. The first one is the dependent variable designated as Y. The second type are explicative variables, usually designated as $X$ (or $X I$ where $I$ is a sequential number of the explicative variable if there are more than one variable). Regression analysis may define dependence between the variables and the contribution of each explanatory variables (regressor) to a change of the dependent variable.

Corporate debt level will be the dependent variable and the factors considered in the previous section will be used as explicative variables. Then it is necessary, first, to decide which indicators will be applied to define the level of corporate debt load.

The most common and well-known indicators which assess corporate debt load are the ones based on the book value, including the debt to equity ratio. It shows the ratio of debt financing to internal financing of the company. A high value of this indicator shows that the company to a serious extent funds its operations employing debt financing which is a signal of possible financial imbalance risks. Nevertheless, this indicator may vary according to the industry sector. For example, if the industry sector in which the company is operating implies large capital expenditures for the conduct of business, this indicator, on average, will be higher than in the sectors which require smaller capital expenditures.

Another important factor is the ratio of total debt to total capital (debt + equity capital) of the company (debt to capital ratio). This indicator manifests which part of corporate total capital (in percentage terms) is financed through debt. As in the previous case, the bigger this indicator the greater the financial imbalance risk of the company.

The frequently used ratio of total debt to company assets (debt to assets ratio) shows which part of corporate aggregate assets is funded through debt financing. This is the interpretation of debt load that we as the dependent variable Y, which designates corporate debt load when building the model:

$$
\mathrm{LEV}=\frac{\mathrm{STDebt}+\text { LTDebt }}{\text { TotalAssets }},
$$

Where LEV represents the corporate debt load (leverage); STDebt stands for corporate short-term debt; and LTDebt represents corporate long-term debt which comprises bank loans and bonds. A list of all variables, their designations and calculation methods are presented in Table 2. 
Table 2. The main variables and their calculation

\begin{tabular}{|c|c|c|}
\hline Variable & Calculation method & Source \\
\hline \multicolumn{3}{|l|}{ Dependent variables } \\
\hline Debt load (LEV) & $\mathrm{LEV}=\frac{\text { TotalDebt }}{\text { TotalAssets }}$ & {$[40 ; 41]$} \\
\hline \multicolumn{3}{|l|}{ Independent variables } \\
\hline Profitability (PROFIT) & PROFIT $=\frac{\text { EBIT }}{\text { TotalAssets }}$ & {$[24 ; 42]$} \\
\hline Tangibility (TANG) & $\mathrm{TANG}=\frac{\text { FixedAssets }}{\text { TotalAssets }}$ & {$[30 ; 41 ; 43]$} \\
\hline Company size (SIZE) & $\mathrm{SIZE}=\ln ($ TotalAssets $)$ & {$[40 ; 41 ; 44]$} \\
\hline $\begin{array}{l}\text { Growth opportunities } \\
\text { (GROWTH) }\end{array}$ & GROWTH $=\frac{\text { Revenue }_{t}}{\text { Revenue }_{t-1}}$ & {$[31]$} \\
\hline Discount rate (WACC) & WACC $=$ Discount rate of the company & $\begin{array}{l}\text { This has not been used as a determinant in } \\
\text { prior research }\end{array}$ \\
\hline Liquidity (LIQ) & $\mathrm{LIQ}=\frac{\text { CurrentAssets }}{\text { CurrentLiabilities }}$ & {$[26]$} \\
\hline Economic efficiency (EFF) & $\mathrm{EFF}=\mathrm{ROA}-\mathrm{WACC}$ & $\begin{array}{l}\text { This has not been used as a determinant in } \\
\text { prior research }\end{array}$ \\
\hline
\end{tabular}

EBIT means earnings before interest on liabilities and income tax, Total Assets means corporate total assets, Fixed Assets means corporate fixed assets (tangible assets), Revenue stands for company proceeds, CurrentAssets means corporate current assets (short-term), and CurrentLiabilities means corporate short-term liabilities.

Where determinants of defining debt load are concerned, the regression model of this research is formally stated as follows:

$$
\begin{aligned}
& \mathrm{LEV}_{\mathrm{it}}=\beta_{0}+\beta_{1}(\mathrm{PROFIT})_{\mathrm{it}}+\beta_{2}(\mathrm{TANG})_{\mathrm{it}}+ \\
& +\beta_{3}(\mathrm{SIZE})_{\mathrm{it}}+\beta_{4}(\mathrm{GROWTH})_{\mathrm{it}}+\beta_{5}(\mathrm{WACC})_{\mathrm{it}}+ \\
& +\beta_{6}(\mathrm{LIQ})_{\mathrm{it}}+\beta_{7}(\mathrm{EFF})_{\mathrm{it}}+\varepsilon_{\mathrm{it}} .
\end{aligned}
$$

In this model, $i$ denotes a company from the sample, and $t$ denotes a corresponding time period.

\section{Research Hypotheses}

The following hypotheses were generated based on the literature review to study debt load determinants. These hypotheses are tested in the present research to verify the compliance with the trade-off theory of capital structure for companies from the Russian and Brazilian markets. The list of tested hypotheses is presented here including relevant determinants on both markets.
Hypothesis No. 1: Profitability exerts a significant negative influence on corporate debt load in emerging markets.

Hypothesis No. 2: Growth opportunities have a significant positive influence on corporate debt load in emerging markets.

Hypothesis No. 3: The company size exerts a significant negative influence on corporate debt load in emerging markets. Hypothesis No. 4: Tangibility has a significant negative influence on corporate debt load in emerging markets.

Hypothesis No. 5: The company discount rate exerts an insignificant influence on corporate debt load in emerging markets.

Hypothesis No. 6: Liquidity has a significant negative influence on corporate debt load in emerging markets.

Hypothesis No. 7: Economic efficiency has a significant negative influence on corporate debt load in emerging markets.

Depending on the confirmed relation between each individual factor and debt-load, we can then establish which theory of capital structure is the most prevalent on emerging markets.

\section{Applied Data}

The main decision criterion to make the list of companies selected during the research was trading their shares or 
bonds in the Russian or Brazilian stock exchange for Russian and Brazilian companies, respectively. The last calendar year was taken as the research period.

The Bloomberg database was used to collect financial indicators to calculate debt load determinants. Due to incomplete financial data for some companies, we experienced problems with the collection of indicators. For this reason, where possible, we used annual reports of companies to add the indicators absent from the Bloomberg database. After sorting the initial data, we eliminated financial sector companies from the sample, removed duplicated data, and eliminated companies with significant gaps in financial information. The final sample comprised 753 Russian and 292 Brazilian companies.

\section{Empirical Analysis of the Research Results}

\section{Results of Econometric Analysis (Russia)}

In the following part, we describe the results of the econometric model presented in the previous section. The calculations were performed with the use of STATA and MS Excel. See below for the results of our analysis of the sample of Russian companies.

First of all, we obtained descriptive statistics of all variables indicated in the previous section for Russian companies. See the data in Table 3.

Table 3. Descriptive statistics of variables

\begin{tabular}{|c|c|c|c|c|c|c|}
\hline Variable & $\begin{array}{l}\text { Number of } \\
\text { observations }\end{array}$ & Average & Median & $\begin{array}{l}\text { Standard } \\
\text { deviation }\end{array}$ & Minimum & Maximum \\
\hline LEV & 753 & 0.2599 & 0.1728 & 0.3442 & 0 & 3.2329 \\
\hline PROFIT & 753 & 0.0572 & 0.0490 & 0.1968 & -3.1388 & 1.6224 \\
\hline TANG & 753 & 0.4095 & 0.3723 & 0.2633 & 0 & 0.9900 \\
\hline SIZE & 753 & 18.1821 & 17.9568 & 2.3120 & 10.9032 & 26.3908 \\
\hline GROWTH & 743 & 1.0465 & 1.0046 & 0.4915 & 0.0700 & 10.8000 \\
\hline WACC & 694 & 11.4210 & 12.0150 & 3.1840 & 3.1600 & 25.7300 \\
\hline LIQ & 753 & 2.9444 & 1.4267 & 6.7463 & 0.0003 & 97.3025 \\
\hline EFF & 753 & -9.1178 & -8.5700 & 18.4079 & -217.8000 & 93.6300 \\
\hline
\end{tabular}

Table 4. Correlation matrix of variables

\begin{tabular}{|c|c|c|c|c|c|c|c|c|}
\hline & LEV & PROFIT & TANG & SIZE & GROWTH & WACC & LIQ & EFF \\
\hline LEV & 1 & & & & & & & \\
\hline PROFIT & 0.0099 & 1 & & & & & & \\
\hline TANG & $0.1008^{\star}$ & 0.0054 & 1 & & & & & \\
\hline SIZE & $0.4106^{*}$ & $0.1154^{*}$ & $0.1801^{\star}$ & 1 & & & & \\
\hline GROWTH & 0.0464 & $0.1329^{*}$ & 0.0916 & $0.1568^{\star}$ & 1 & & & \\
\hline WACC & $-0.8544^{\star}$ & 0.0362 & 0.0264 & $-0.3250^{*}$ & -0.0186 & 1 & & \\
\hline LIQ & $-0.4158^{\star}$ & 0.0947 & $-0.2779^{\star}$ & $-0.1622^{\star}$ & -0.0364 & $0.5087^{\star}$ & 1 & \\
\hline $\mathrm{EFF}$ & -0.018 & $0.4776^{*}$ & -0.0616 & -0.0036 & $0.1299^{*}$ & 0.0244 & $0.1067^{\star}$ & 1 \\
\hline
\end{tabular}

*a 1\% significance level. 
The following conclusions may be made based on the above data. First of all it should be noted that, on average, the debt-load of Russian companies amounts to approximately $26 \%$ (although the sample comprises companies without debt load). The average profitability of companies was just $6 \%$ - but at the same time, the capital intensity of Russian companies is rather high because the share of fixed assets in total assets on average exceeds $40 \%$. The size indicator shows that the sample contains rather large companies as well as significantly smaller ones. The indicator of growth opportunities illustrates that the sample comprises companies at different development stages. The liquidity indicator shows that on average Russian companies have a good current ratio, which allows them to cover their current liabilities. At the same time, the economic efficiency indicator demonstrates clearly that, on average, Russian companies show no efficiency.

Subsequently, we have studied the probability distribution of the variables included in the models based on the graph method. See the results in Appendix 1. Then, a correlation matrix was made for the used variables (Table 4).

Analysis shows a significant dependence between debt load and the majority of the determinants mentioned above. A positive relationship is observed between the company size and tangibility, while a negative relationship was revealed for the variables, which define the discount rate of the company and its liquidity. According to the results, we can also state that there is no significant correlation between debt load and profitability. A significant correlation was revealed between efficiency and growth opportunities in this sample. The correlation is considered to be significant if the correlation coefficient between variables exceeds 0.7 (and this is the case only with the discount rate variable). It makes sense from the empirical point of view, because the higher the corporate required profitability, the higher interest the company pays for new debt and thus the new debt becomes less attractive for the company.

Then, we built a regression model based on the equation presented in the next section. The corporate debt load (LEV) is used as the dependent variable. In this model, we replaced the EFF variable, which stands for efficiency with the DEFF dummy variable, which takes on the value of 1 if the company is efficient (ROA $>$ WACC) and correspondingly takes on the value of 0 if, on the contrary, the company is not efficient $(\mathrm{ROA}<\mathrm{WACC})$. See the results of the model in Table 5.

Table 5. Results of model evaluation

\begin{tabular}{lc}
\multicolumn{1}{c}{ LEV } \\
PROFIT & -0.0268 \\
\hline TANG & $0.0938^{\star * \star}$ \\
\hdashline SIZE & $0.0154^{\star * *}$ \\
\hline GROWTH & $-0.0304^{\star}$ \\
\hline WACC & $-0.0548^{\star * *}$
\end{tabular}

\begin{tabular}{|c|c|}
\hline & LEV \\
\hline LIQ & -0.0007 \\
\hline DEFF & 0.0401 \\
\hline CONS & $0.5588^{\star * *}$ \\
\hline
\end{tabular}

Adj R-squared

0.4663

${ }^{\star * *}$ a $1 \%$ significance; ${ }^{* *}$ a $5 \%$ significance; ${ }^{\star}$ a $10 \%$ significance.

The average R-square in the model takes on an acceptable value of 0.4663 , i.e., the defined independent variables in the model explain a little less than $50 \%$ of changes of the dependent variable. According to Fisher's criterion, at a 0.01 significance level, the zero hypotheses of statistical insignificance of regression is rejected. This means that the equation in general is statistically significant. Several points concerning this model should be explained. First of all, the profitability indicator is not significant at any level. Besides, at a $1 \%$ significance level, the variables designating tangibility, size, discount rate and the constant turned out to be important. The positive significant relation between tangibility (the share of fixed assets in corporate assets to be more exact), and corporate debt load confirm both theories of capital structure because it shows that the more opportunities a company has to offer a pledge to secure a debt, the higher that company's debt load. A positive significant relationship between the company size and debt load confirms the trade-off theory of capital structure and indicates that it is expressed in smaller risks of bankruptcy and financial imbalance and in more stable cash flows. A negative significant relationship between the discount rate of a company and its debt load shows that in this case, companies act more following the trade-off theory of capital structure because capital structure influences their debt load.

At the same time, the growth opportunities variable turned out to be significant only at a $10 \%$ level, while other variables were statistically insignificant. Thus, in this model the following hypotheses were not confirmed for Russian companies:

Hypothesis No. 1: Profitability exerts a significant negative influence on corporate debt load in the Russian market (insignificant influence).

Hypothesis No. 3: The company size exerts a significant negative influence on corporate debt load in the Russian market (significant positive influence - the trade-off theory).

Hypothesis No. 4: Tangibility has a significant negative influence on corporate debt load in in the Russian market (significant positive influence - the trade-off theory).

Hypothesis No. 5: The company discount rate exerts an insignificant influence on corporate debt load in the Russian market (significant negative influence - the trade-off theory).

Hypothesis No. 6: Liquidity has a significant negative influence on corporate debt load in the Russian market (insignificant influence). 
Hypothesis No. 7: Economic efficiency has a significant negative influence on corporate debt load in the Russian market (insignificant influence).

Hypothesis No. 2 was confirmed partially:growth opportunities have a significant positive influence on corporate debt load in the Russian market (significant at a 10\% level, negative influence - the trade-off theory).

\section{Results of econometric analysis (Brazil)}

Further, we show the results of the analysis of the sample comprising Brazilian companies. The sample of Brazilian companies was studied in the same way as that of Russian companies. First, we obtained descriptive statistics of all variables. See the data in Table 6.

Table 6. Descriptive statistics of variables

\begin{tabular}{|c|c|c|c|c|c|c|}
\hline Variable & $\begin{array}{l}\text { Number of } \\
\text { observations }\end{array}$ & Average & Median & $\begin{array}{l}\text { Standard } \\
\text { deviation }\end{array}$ & Minimum & Maximum \\
\hline $\mathrm{LEV}$ & 292 & 0.3577 & 0.2997 & 0.4071 & 0.0000 & 4.7325 \\
\hline PROFIT & 292 & 0.0371 & 0.0601 & 0.1444 & -1.0339 & 0.3108 \\
\hline TANG & 292 & 0.2631 & 0.2272 & 0.2112 & 0.0000 & 0.9993 \\
\hline SIZE & 292 & 20.1761 & 20.2347 & 1.9317 & 15.0144 & 25.9709 \\
\hline GROWTH & 288 & 1.1079 & 1.0300 & 0.3702 & 0.2500 & 3.5000 \\
\hline WACC & 292 & 13.5186 & 13.8900 & 2.1992 & 3.6300 & 20.1300 \\
\hline LIQ & 291 & 2.4173 & 1.6661 & 4.6423 & 0.0005 & 66.4670 \\
\hline EFF & 292 & -13.4457 & -11.1400 & 14.0992 & -82.0600 & 13.9900 \\
\hline
\end{tabular}

The following conclusions may be made based on the obtained data.

The average debt load of Brazilian companies, on average, amounts to $36 \%$ which is $10 \%$ more than that of Russian companies. Average profitability amounts to approximately $4 \%$ which is a little less than the profitability of Russian companies (6\%). Besides, Brazilian companies, unlike Russian ones, show a significantly lower capital intensity - the share of fixed assets in the total assets, on average, amounts to approximately $26 \%$. The size indicator indicates that the sample comprises both large and small companies. The indicator of growth opportunities shows that the sample en- compasses companies of various development stages. The liquidity indicator illustrates that Brazilian companies have a good current ratio on average. At the same time, the economic efficiency indicator, in the same way as with Russian companies, shows that on average Brazilian companies are less effective.

Subsequently, the probability distribution of the variables was studied applying the graph method (Appendix 2), and a correlation matrix was made for the used variables (Table 7).

Table 7. Correlation matrix of variables

\begin{tabular}{|c|c|c|c|c|c|c|c|c|}
\hline & LEV & PROFIT & TANG & SIZE & GROWTH & WACC & LIQ & EFF \\
\hline LEV & 1 & & & & & & & \\
\hline PROFIT & -0.0877 & 1 & & & & & & \\
\hline TANG & $0.2061^{\star}$ & 0.0443 & 1 & & & & & \\
\hline SIZE & $0.2482^{\star}$ & 0.1327 & -0.017 & 1 & & & & \\
\hline GROWTH & -0.0127 & $0.1701^{\star}$ & 0.0076 & 0.0738 & 1 & & & \\
\hline WACC & $-0.4495^{\star}$ & -0.054 & $-0.1912^{\star}$ & -0.0101 & 0.1028 & 1 & & \\
\hline LIQ & $-0.3587^{\star}$ & $0.1610^{*}$ & $-0.2026^{\star}$ & -0.0096 & 0.1051 & $0.4146^{*}$ & 1 & \\
\hline EFF & -0.1359 & $0.3880^{\star}$ & 0.0319 & $-0.2164^{\star}$ & 0.0345 & -0.0304 & 0.1163 & 1 \\
\hline
\end{tabular}

* a $1 \%$ significance level. 
Analysis shows that there is a significant dependence between debt load and the same determinants which have been used for Russian companies. A positive relationship is observed between the company size and tangibility while a negative correlation was detected for the variables which define the discount rate of the company and its liquidity. As in the Russian companies' sample, no significant correlation was revealed between debt load and profitability, efficiency and growth opportunities. No significant correlation is observed between the variables (the correlation ratio exceeds 0.7 ).

We subsequently built a regression model. The corporate debt load (LEV) is used as the dependent variable. In this model, as in the Russian companies' sample, we replaced the EFF variable which stands for efficiency with the DEFF dummy variable. See the results of the model in Table 8.

Table 8. Results of model evaluation

\begin{tabular}{|c|c|}
\hline & LEV \\
\hline PROFIT & $-0.0268^{\star *}$ \\
\hline TANG & $0.0938^{\star}$ \\
\hline SIZE & 0.0154 \\
\hline GROWTH & -0.0304 \\
\hline WACC & $-0.0548^{* * *}$ \\
\hline LIQ & $-0.0007^{\star *}$ \\
\hline DEFF & 0.0401 \\
\hline CONS & $0.5588^{\star * *}$ \\
\hline Adj R-squared & 0.1581 \\
\hline
\end{tabular}

The average R-square in the model amounts to 0.1581 , which is significantly lower than in the Russian samples. The zero hypothesis of statistical insignificance of this regression is rejected at the 0.01 significance level according to Fisher's criterion. This means that the equation is statistically significant in general. Several points of this model need to be clarified. First of all, in this sample, the profitability indicator turned out to be significant at a 5\% level with a negative relation, thus confirming the pecking order theory because the company prefers to rely on its own sources. Additionally, the liquidity indicator was significant at a $5 \%$ level with a negative relation, which also confirms the pecking order theory. Only the tangibility variable was at a $10 \%$ significance level.

At the same time, at a $1 \%$ significance level, only the discount rate variable and the constant were of importance. A significant negative relationship between the corporate discount rate and its debt load shows that in this case, companies act more according to the trade-off theory of capital structure because capital structure influences their debt load.

Besides, other variables turned out to be statistically insignificant. Thus, in this model, the following hypotheses have been confirmed for Brazilian companies.
Hypothesis No. 2: Growth opportunities have a significant positive influence on corporate debt load in the market (insignificant influence).

Hypothesis No. 3: The company size exerts a significant negative influence on corporate debt load in the market (insignificant influence).

Hypothesis No. 5: The company discount rate exerts an insignificant influence on corporate debt load in the market (significant negative influence - the trade-off theory).

Hypothesis No. 7: Economic efficiency has a significant negative influence on corporate debt load in the market (insignificant influence).

The following hypotheses were confirmed partially:

Hypothesis No. 1: Profitability exerts a significant negative influence on corporate debt load in the market (a 5\% significance, negative influence - the pecking order theory).

Hypothesis No. 4: Tangibility has a significant negative influence on corporate debt load in the market (a 10\% significance, positive influence - the trade-off theory).

Hypothesis No. 6: Liquidity has a significant negative influence on corporate debt load in the market (a 5\% significance, negative influence - the pecking order theory).

\section{Conclusion}

In this paper we have analyzed determinants of the debt load level for a sample of Russian and Brazilian companies in 2020. The sample consists of 753 Russian companies and 292 Brazilian companies. We identified that the same set of determinants differs significantly in explanatory power and suits Russian companies much better than Brazilian ones. Moreover, it was established that on the basis of this set of determinants, it is impossible to identify with confidence which of the two theories companies are most likely to follow in their actions, because the observed interrelations between the examined factors and debt load have indications of the trade-off theory as well as the pecking order theory.

It should be also noted that the WACC variable, specifying the cost of capital turned out to be significant for both samples. This confirms the dependence of debt load on capital structure for companies in both Russia and Brazil. At the same time, the result that economic efficiency has no significant impact on corporate debt load is representative. It may signal to the management that this aspect should be taken into consideration when defining the optimal level of corporate debt load.

In general, and in conclusion, we may also postulate that the issue of economic efficiency and the link thereof to corporate debt is of interest for further study from the point of view of corporate capital structure in markets other than the ones studied presently. Further, we may propose that the operations of certain companies in 2020 in different economic, social, business and cultural contexts widely varies and complicates the strict application of conventional academic theories articulated thus far. 


\section{Acknowledgment}

In this paper we acknowledge the support of the Metropolitan University Prague research project no. 87-02 "International Business, Financial Management and Tourism" (2021), based on a grant from the Institutional fund for the Long-term Strategic Development of Research Organizations

\section{References}

1. Modigliani F., Miller M.H. The cost of capital, corporation finance and the theory of investment. The American Economic Review. 1958;48(3):261-297.

2. Kraus A., Litzenberger R.H. A state-preference model of optimal financial leverage. The Journal of Finance. 1973;28(4):911-922. https://doi. org/10.1111/j.1540-6261.1973.tb01415.x

3. Miller M.H. Debt and taxes. The Journal of Finance. 1977;32(2):261-275. https://doi. org/10.1111/j.1540-6261.1977.tb03267.x

4. Scott J.H. Bankruptcy, secured debt, and optimal capital structure. The Journal of Finance. 1977;32(1):119. https://doi.org/10.1111/j.1540-6261.1977. tb03237.x

5. Kim E.H. A mean-variance theory of optimal capital structure and corporate debt capacity. The Journal of Finance. 1978;33(1):45-63. DOI: https://doi. org/10.1111/j.1540-6261.1978.tb03388.x

6. Myers S.C. Capital structure. Journal of Economic Perspectives. 2001;15(2):81-102. https://doi. org/10.1257/jep.15.2.81

7. Jensen M.C., Meckling W.H. Theory of the firm: Managerial behavior, agency costs and ownership structure. Journal of Financial Economics. 1976;3(4):305-360. https://doi.org/10.1016/0304405X(76)90026-X

8. Demsetz $\mathrm{H}$. The theory of the firm revisited. The Journal of Law, Economics, and Organization. 1988;4(1):141-161. https://doi.org/10.1093/ oxfordjournals.jleo.a036941

9. Holmstrom B.R., Tirole J. The theory of the firm. In: Schmalensee R., Willig R., eds. Handbook of industrial organization. Amsterdam: North Holland; 1989;1:61-133. (Handbooks in Economics. Vol. 10). https://doi.org/10.1016/S1573-448X(89)01005-8

10. Rajan R.G., Zingales L. Power in a theory of the firm. The Quarterly Journal of Economics. 1998;113(2):387432. https://doi.org/10.1162/003355398555630

11. Myers S.C., Maljuf N.S. Corporate financing and investment decisions when firms have information that investors do not have. Journal of Financial Economics. 1984;13(2):187-221. https://doi. org/10.1016/0304-405X(84)90023-0
12. Myers S.C. The capital structure puzzle. The Journal of Finance. 1984;39(3):574-592. https://doi. org/10.1111/j.1540-6261.1984.tb03646.x

13. Frank M.Z., Goyal V.K. Testing the pecking order theory of capital structure. Journal of Financial Economics, 2003;67(2):217-248. https://doi. org/10.1016/S0304-405X(02)00252-0

14. Jindřichovská I., Körner P. Determinants of corporate financing decisions: A survey evidence from Czech firms. IES Working Paper. 2008;(1). URL: https:// core.ac.uk/download/pdf/7134127.pdf

15. Sheikh J., Ahmed W.A., Iqbal W., Masood M.M. Pecking at pecking order theory: Evidence from Pakistan's non-financial sector. Journal of Competitiveness. 2012;4(4):86-95. https://doi. org/10.7441/joc.2012.04.06

16. Lucas D.J., McDonald R.L. Equity issues and stock price dynamics. The Journal of Finance. 1990;45(4):1019-1043. https://doi. org/10.1111/j.1540-6261.1990.tb02425.x

17. Elliott W.B., Koëter-Kant J., Warr R.S. Market timing and the debt-equity choice. Journal of Financial Intermediation. 2008;17(2);175-197. https://doi. org/10.1016/j.jfi.2007.05.002

18. Jahanzeb A., Saif-Ur-Rehman, Bajuri N., Karami M., Ahmadimousaabad A. Tradeoff theory, pecking order theory and market timing theory: A comprehensive review of capital structure theories. International Journal of Management and Commerce Innovations. 2013;1(1):11-18. URL: https://www.researchgate. net/publication/264422625_Trade-Off_Theory_ Pecking_Order_Theory_and_Market_Timing_ Theory_A_Comprehensive_Review_of_Capital_ Structure_Theories

19. Nunkoo P.K., Boateng A. The empirical determinants of target capital structure and adjustment to longrun target: Evidence from Canadian firms. Applied Economics Letters. 2010;17(10):983-990. https://doi. org/10.1080/17446540802599671

20. Danis A., Rettl D.A., Whited T.M. Refinancing, profitability, and capital structure. Journal of Financial Economics. 2014;114(3):424-443. https:// doi.org/10.1016/j.jfineco.2014.07.010

21. Dasilas A., Papasyriopoulos N. Corporate governance, credit ratings and the capital structure of Greek SME and large listed firms. Small Business Economics. 2015;45(1):215-244. https://doi. org/10.1007/s11187-015-9648-y

22. La Rocca M., La Rocca T., Cariola A. Capital structure decisions during a firm's life cycle. Small Business Economics. 2011;37(1):107-130. https://doi. org/10.1007/s11187-009-9229-Z 
23. Öztekin Ö. Capital structure decisions around the world: Which factors are reliably important? Journal of Financial and Quantitative Analysis. 2013;50(3):301-323. https://doi.org/10.1017/ S0022109014000660

24. Vo X.V. Determinants of capital structure in emerging markets: evidence from Vietnam. Research in International Business and Finance. 2017;40:105113. https://doi.org/10.1016/j.ribaf.2016.12.001

25. Asen A., Nwude C.E., Idamoyibo H.R., Ufodiama C.N., Udo E.S. Effect of capital structure on firms performance in Nigeria. Universal Journal of Accounting and Finance. 2021;9(1):15-23. https://doi. org/10.13189/ujaf.2021.090102

26. Neves M.E., Henriques C., Vilas J. Financial performance assessment of electricity companies: evidence from Portugal. Operational Research. 2021;21(4):2809-2857. https://doi.org/10.1007/ s12351-019-00504-1

27. Fama E.F., French K.R. Testing trade-off and pecking order predictions about dividends and debt. The Review of Financial Studies. 2002;15(1):1-33. https:// doi.org/10.1093/rfs/15.1.1

28. Dang V.A., Kim M., Shin Y. Asymmetric adjustment toward optimal capital structure: Evidence from a crisis. International Review of Financial Analysis. 2014;33:226-242. https://doi.org/10.1016/j. irfa.2014.02.013

29. Jindrichovska I., Ugurlu E., Kubickova D. Changes in capital structure of Czech SMEs: A dynamic panel data approach. Ekonomika a management, 2013;(3):121. URL: https://www.vse.cz/eam/202

30. Serrasqueiro Z., Matias F., Salsa L. Determinants of capital structure: New evidence from Portuguese small firms. Dos Algarves: A Multidisciplinary e-Journal. 2016;(28):13-28. https://doi.org/10.18089/ DAMeJ.2016.28.2

31. Köksal B., Orman C. Determinants of capital structure: Evidence from a major developing economy. Small Business Economics. 2015;44(2):255282. https://doi.org/10.1007/s11187-014-9597-x

32. Titman S., Wessels R. The determinants of capital structure choice. The Journal of Finance. 1988;43(1):119. https://doi.org/10.1111/j.1540-6261.1988. tb02585.x

33. Ozkan A. Determinants of capital structure and adjustment to long run target: Evidence from UK Company Panel Data. Journal of Business Finance \& Accounting. 2001;28(1-2):175-198. https://doi. org/10.1111/1468-5957.00370

34. Matias F., Serrasqueiro Z. Are there reliable determinant factors of capital structure decisions? Empirical study of SMEs in different regions of
Portugal. Research in International Business and Finance. 2017;40:19-33. 10.1016/j.ribaf.2016.09.014

35. Nahar S., Azim M., Anne Jubb C. Risk disclosure, cost of capital and bank performance. International Journal of Accounting \& Information Management. 2016;24(4):476-494. https://doi.org/10.1108/ IJAIM-02-2016-0016

36. Andres C., Cumming D., Karabiber T., Schweizer D. Do markets anticipate capital structure decisions? - Feedback effects in equity liquidity. Journal of Corporate Finance. 2014;27:133-156. https://doi. org/10.1016/j.jcorpfin.2014.02.006

37. Dang V.A., Garrett I. On corporate capital structure adjustments. Finance Research Letters. 2015;14:56-63. https://doi.org/10.1016/j.frl.2015.05.016

38. Cheng S.-R., Shiu C.-Y. Investor protection and capital structure: International evidence. Journal of Multinational Financial Management. 2007;17(1):3044. https://doi.org/10.1016/j.mulfin.2006.03.002

39. Ahmed Sheikh N., Wang Z. Determinants of capital structure: An empirical study of firms in manufacturing industry of Pakistan. Managerial Finance. 2011;37(2):117-133. https://doi. org/10.1108/03074351111103668

40. Sogorb-Mira F. How SME uniqueness affects capital structure: Evidence from a 1994-1998 Spanish data panel. Small Business Economics. 2005;25(5):447-457. https://doi.org/10.1007/s11187-004-6486-8

41. Neves M.E., Serrasqueiro Z., Dias A., Hermano C. Capital structure decisions in a period of economic intervention: Empirical evidence of Portuguese companies with panel data. International Journal of Accounting \& Information Management. 2020;28(3):465-495. https://doi.org/10.1108/ IJAIM-08-2019-0094

42. Rajan R.G., Zingales L. What do we know about capital structure? Some evidence from international data. The Journal of Finance. 1995;50(5):1421-1460. https://doi.org/10.1111/j.1540-6261.1995.tb05184.x

43. Abor J., Biekpe N. How do we explain the capital structure of SMEs in Sub-Saharan Africa? Evidence from Ghana. Journal of Economic Studies. 2009;36(1):83-97. https://doi. org/10.1108/01443580910923812

44. Vieira E.S., Neves M.E., Dias A.G. Determinants of Portuguese firms' financial performance: Panel data evidence. International Journal of Productivity and Performance Management. 2019;68(7):1323-1342. https://doi.org/10.1108/IJPPM-06-2018-0210 


\section{Appendix 1 (Russia)}

\section{LEV probability distribution}

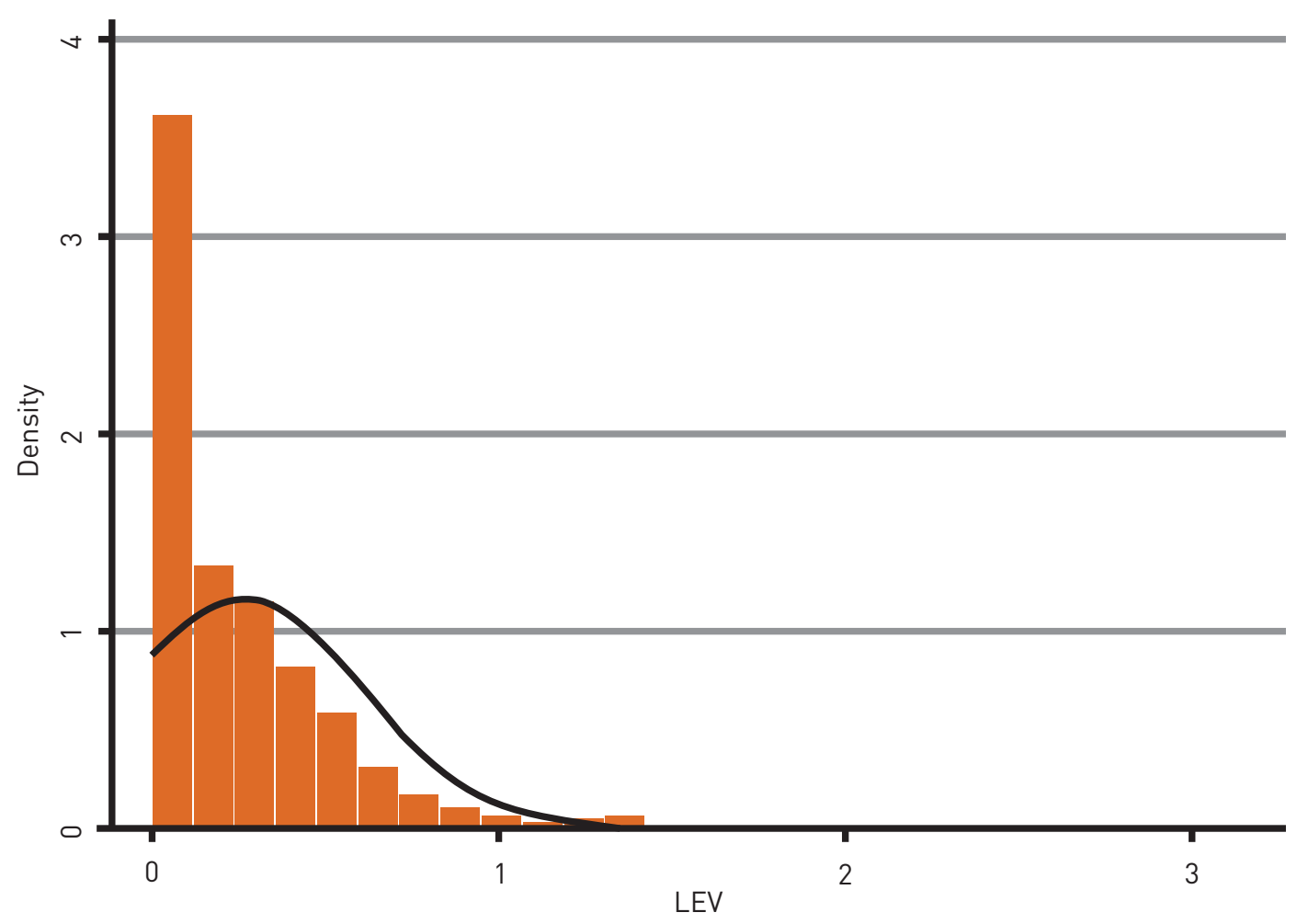

PROFIT probability distribution

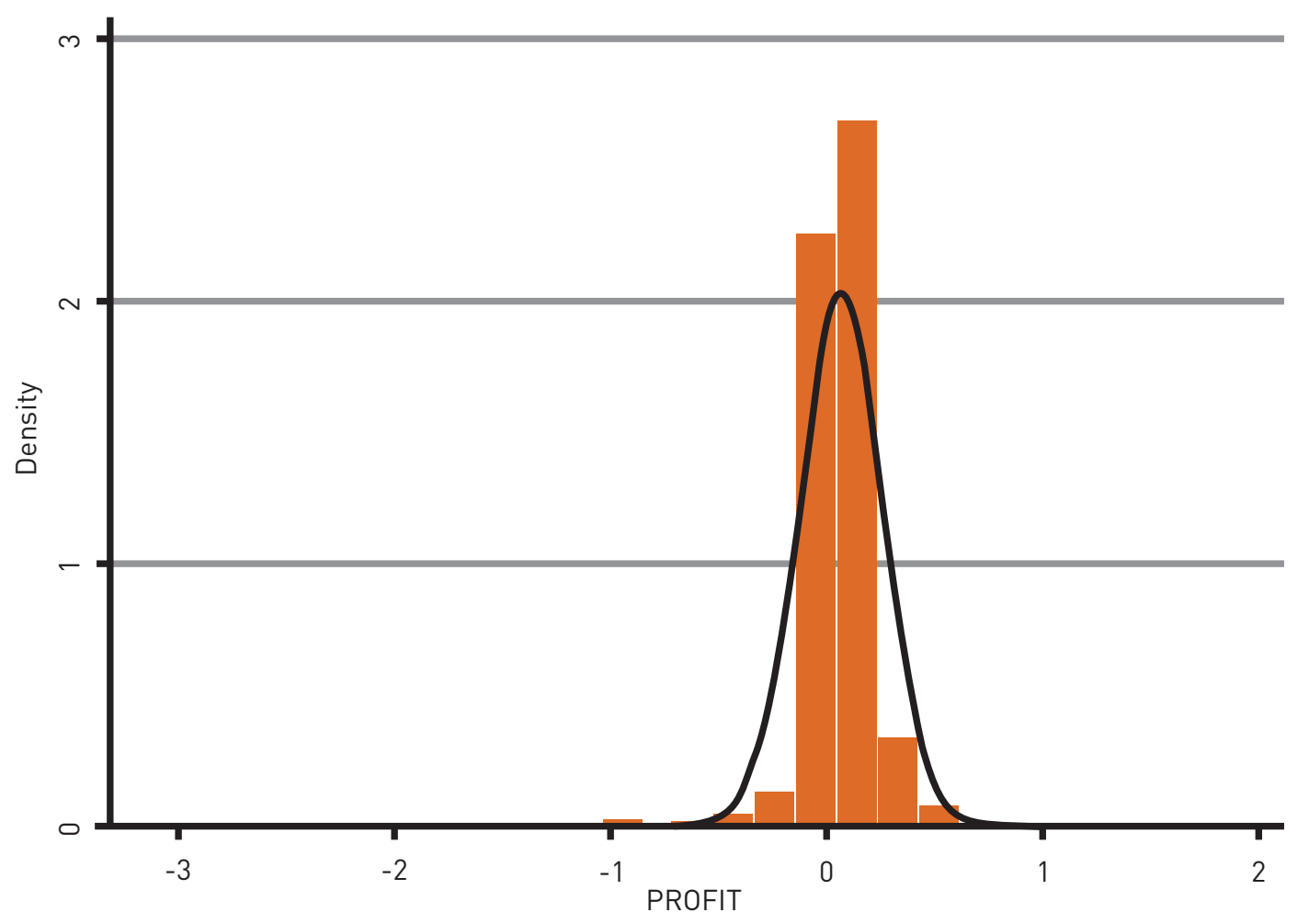




\section{TANG probability distribution}

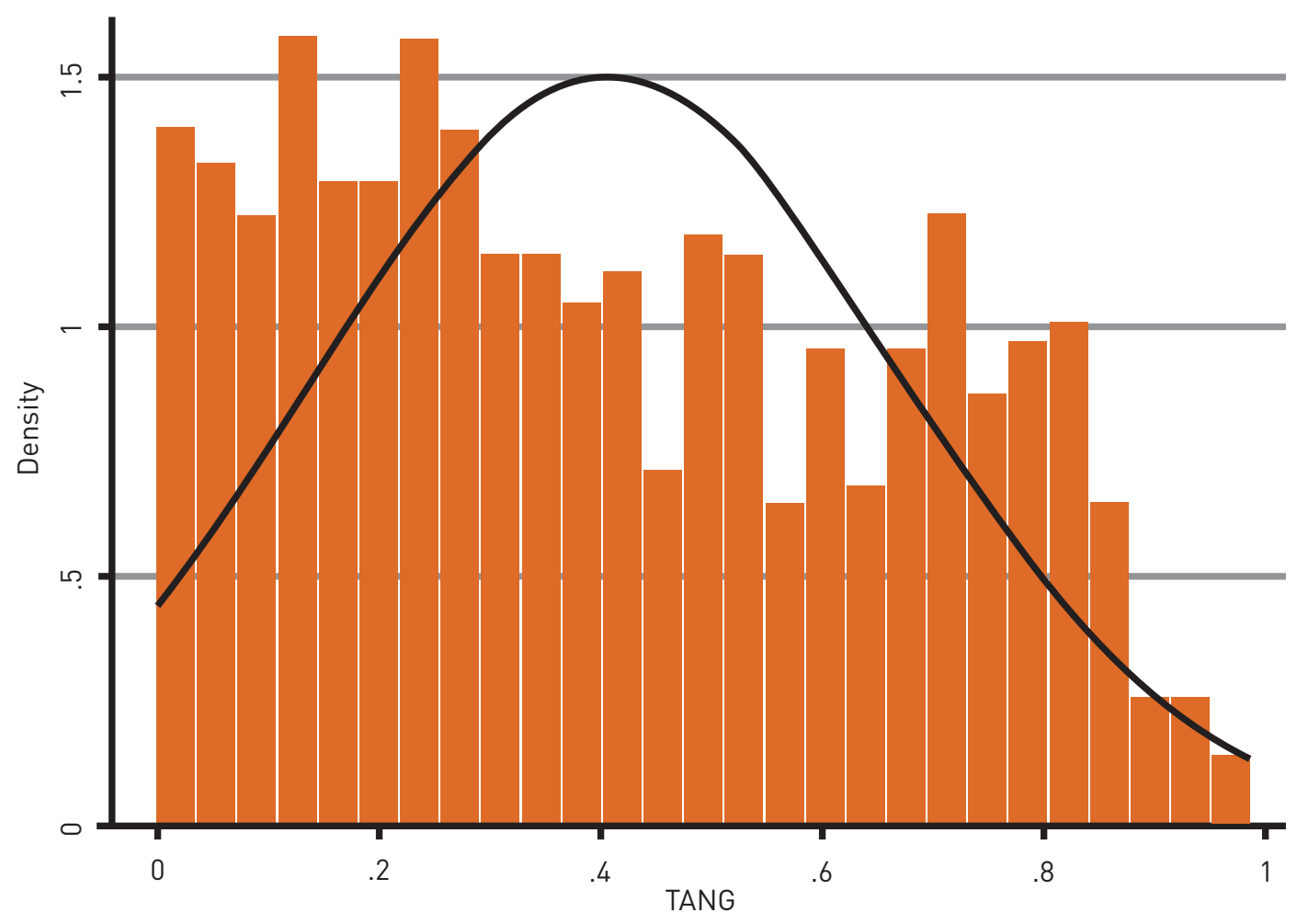

\section{SIZE probability distribution}

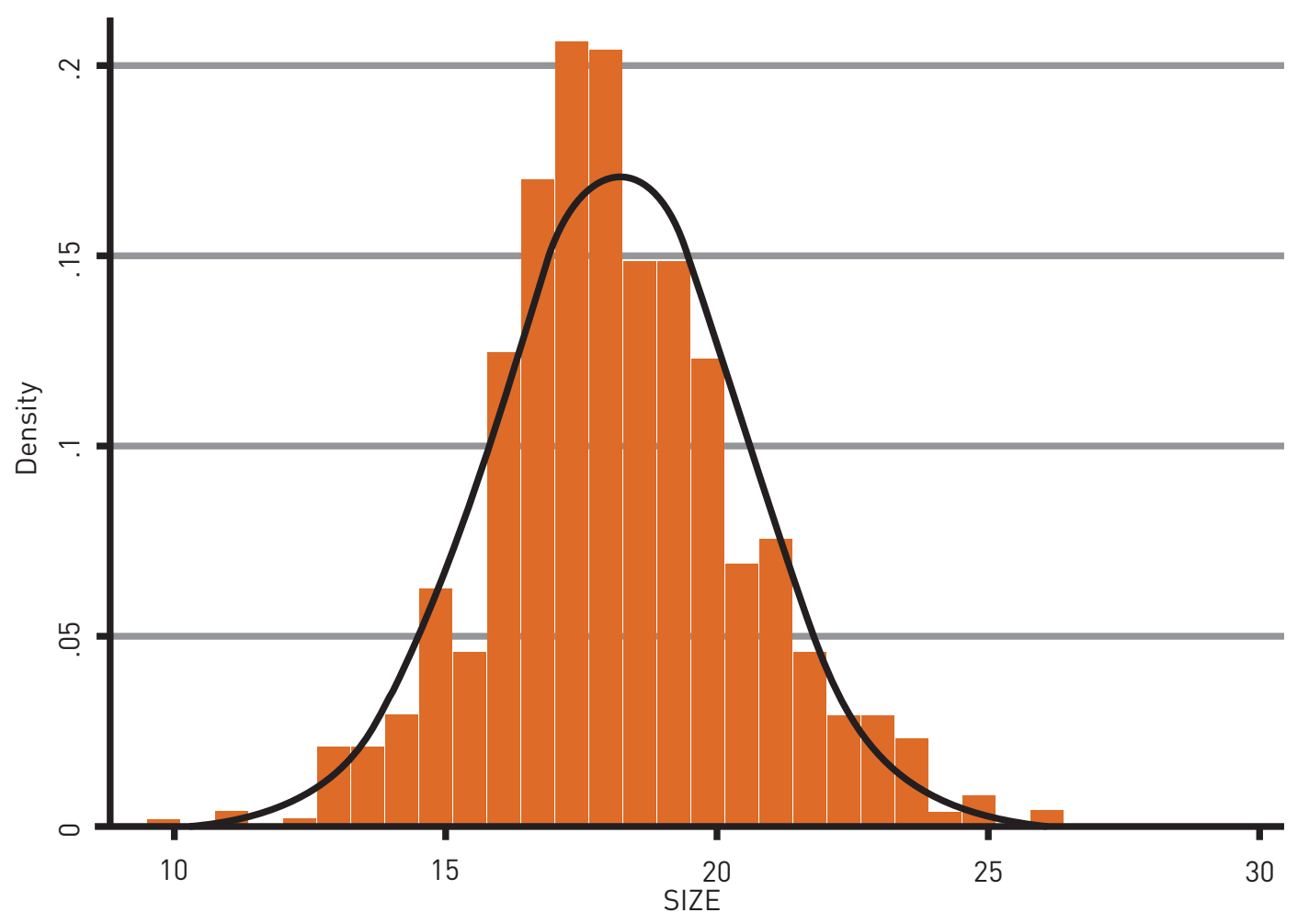




\section{GROWTH probability distribution}

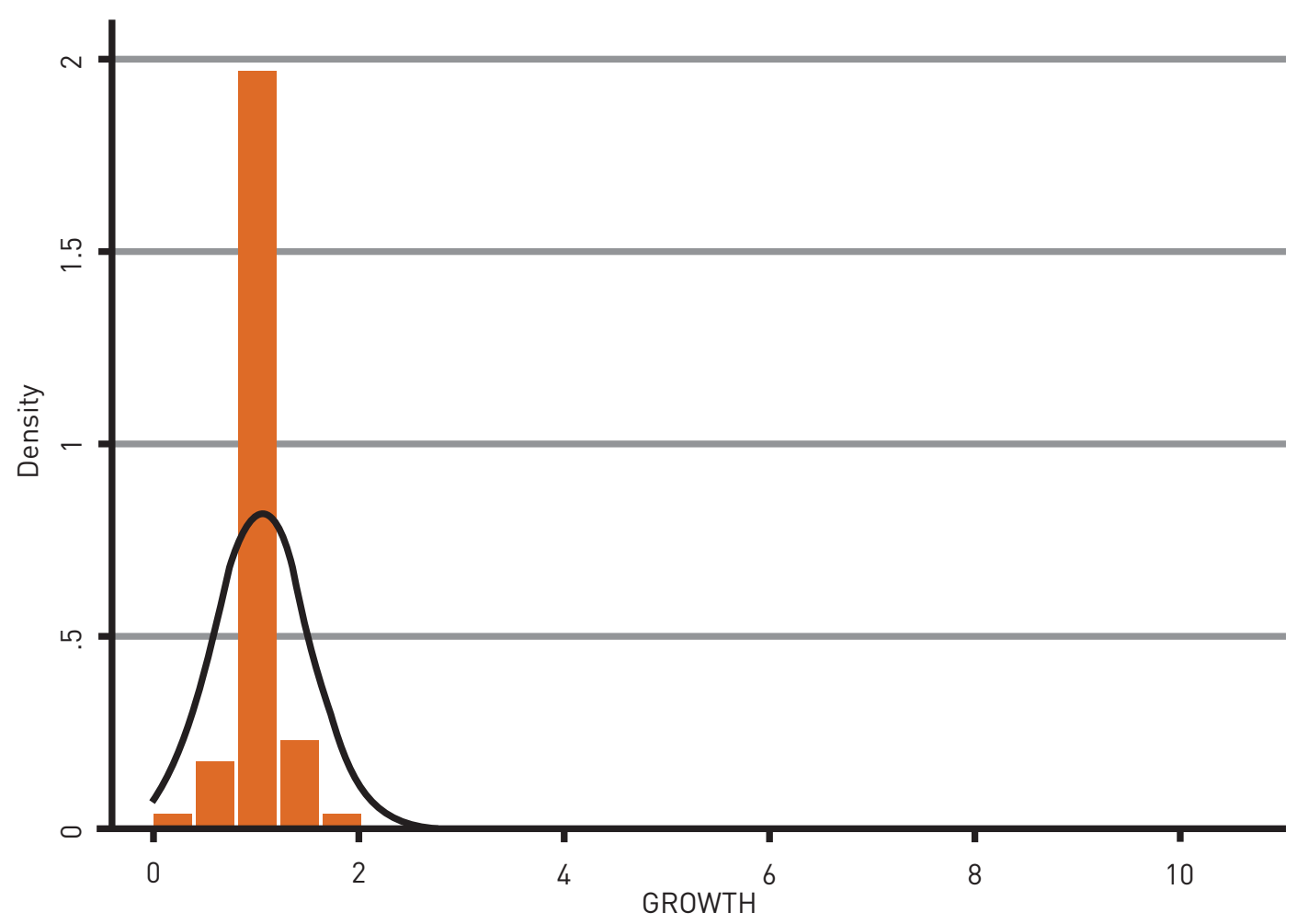

WACC probability distribution

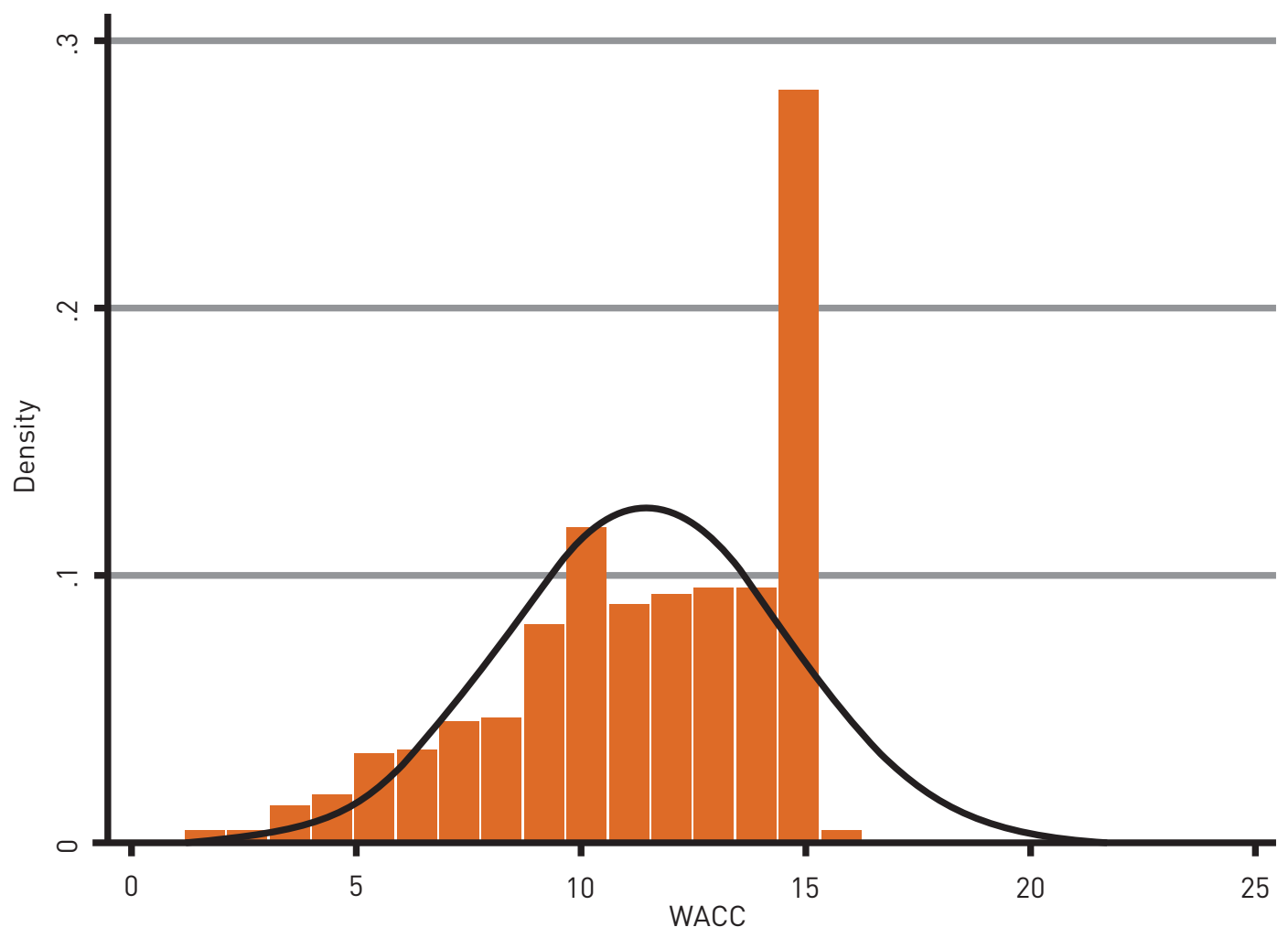




\section{LIQ probability distribution}

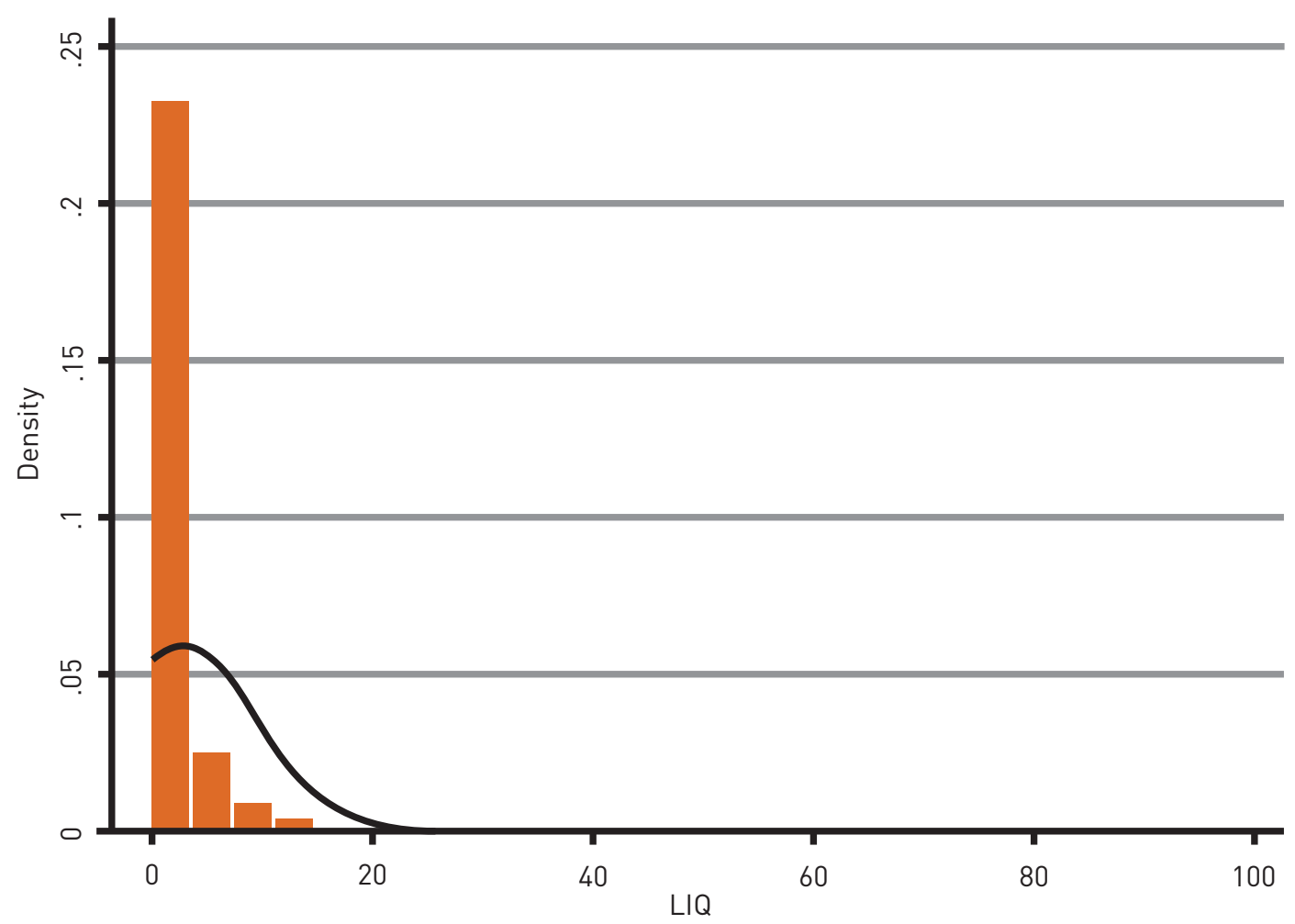

\section{EFF probability distribution}

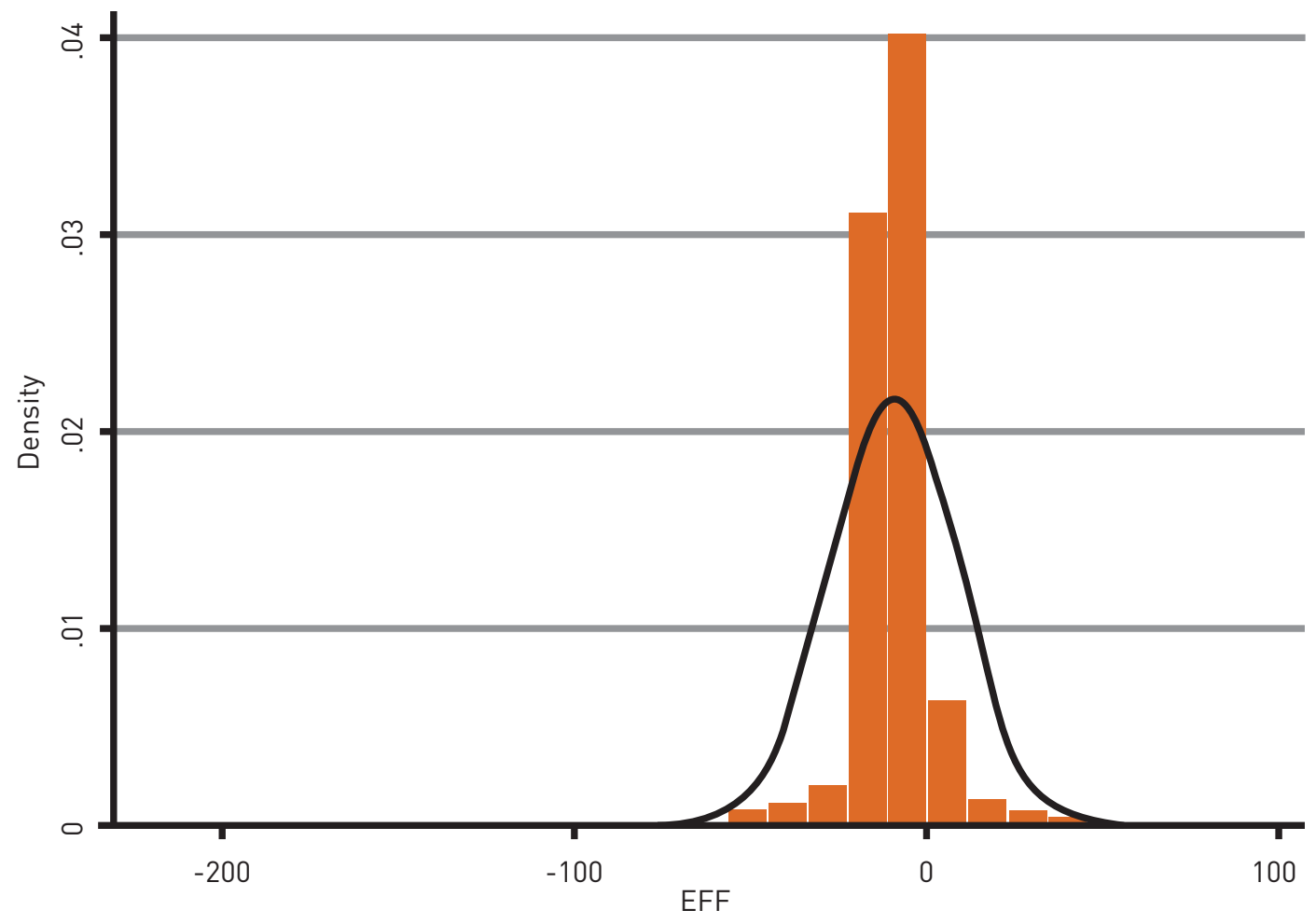




\section{Appendix 2 (Brazil)}

\section{LEV probability distribution}

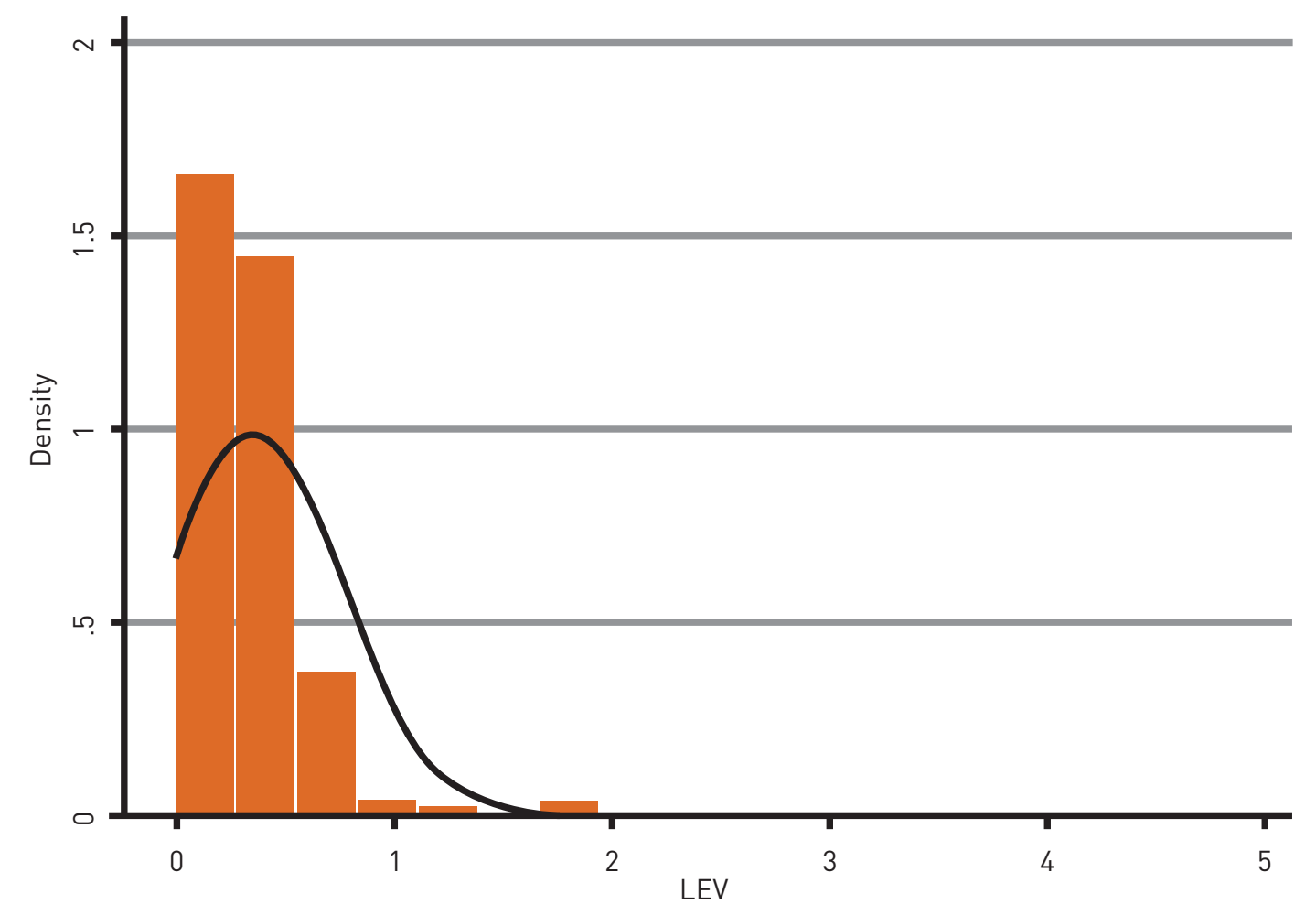

\section{PROFIT probability distribution}

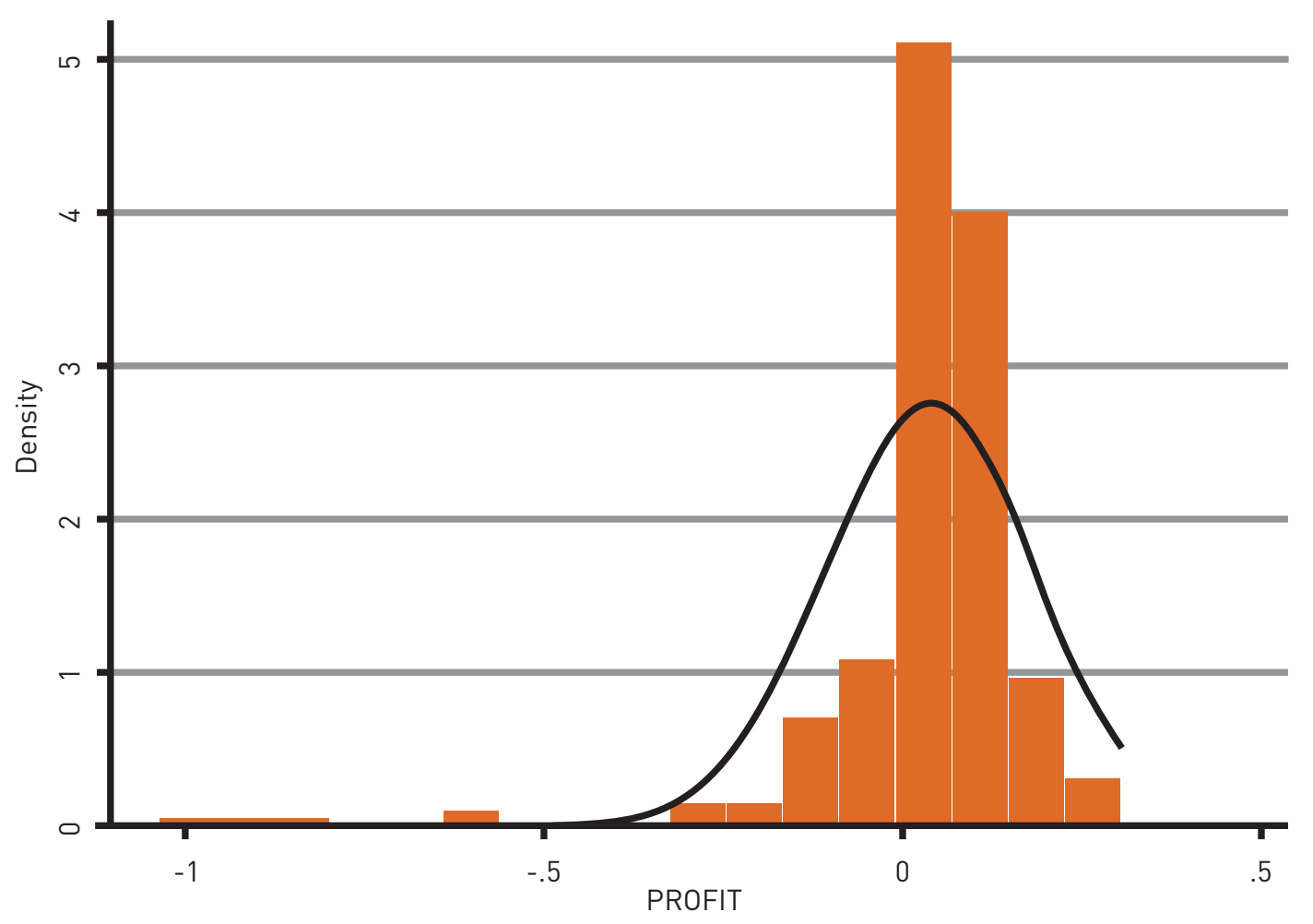




\section{TANG probability distribution}

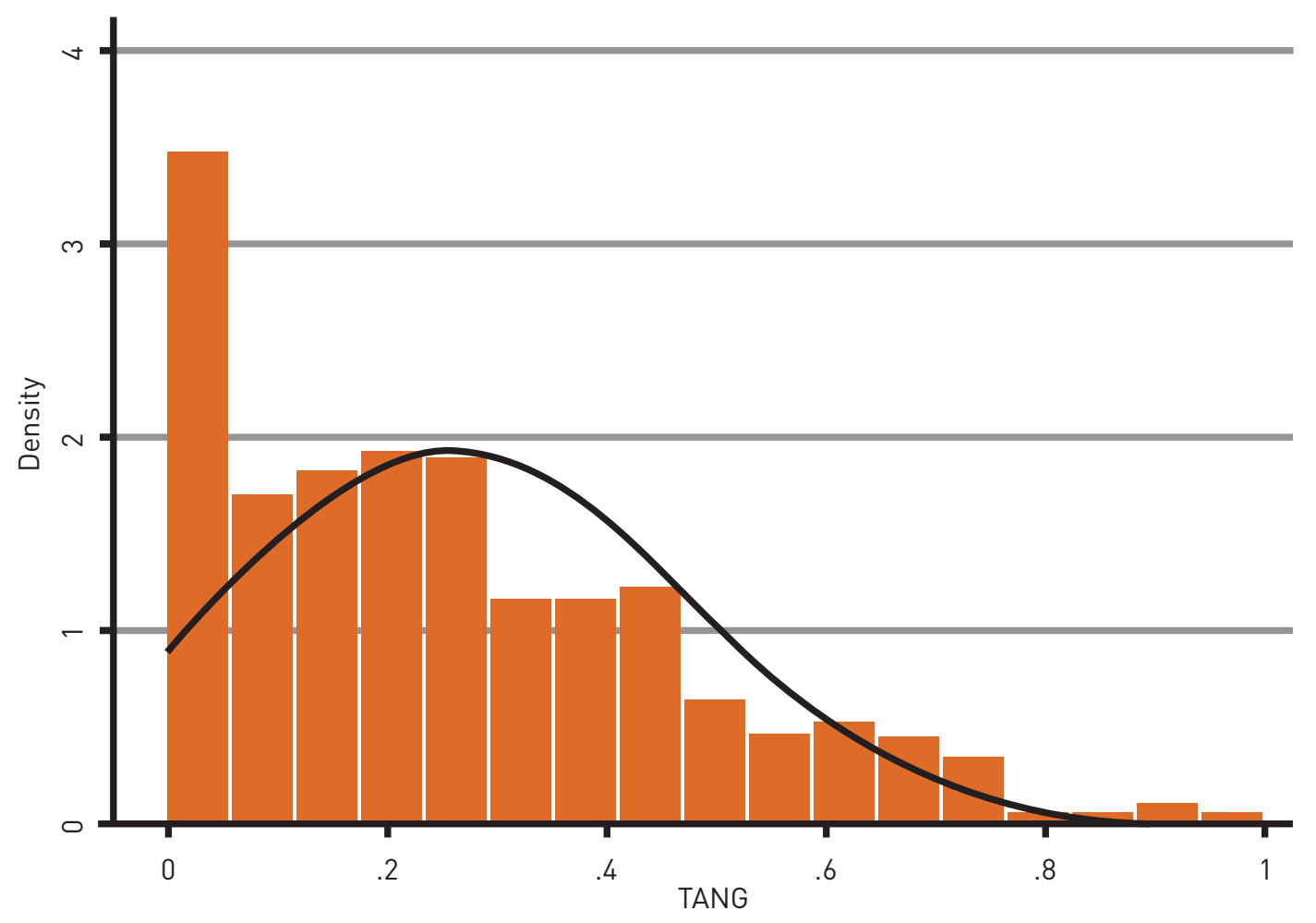

\section{SIZE probability distribution}

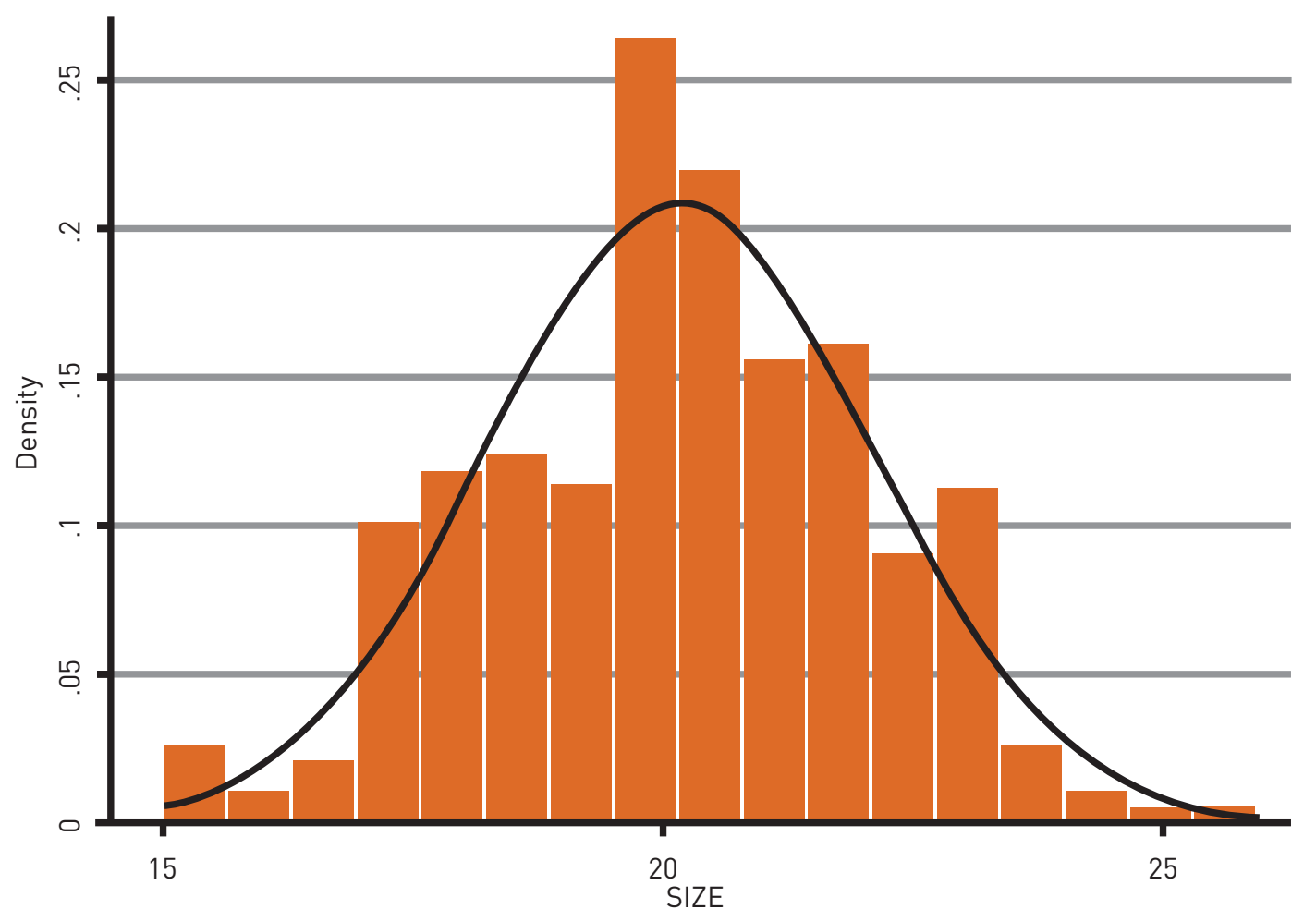




\section{GROWTH probability distribution}

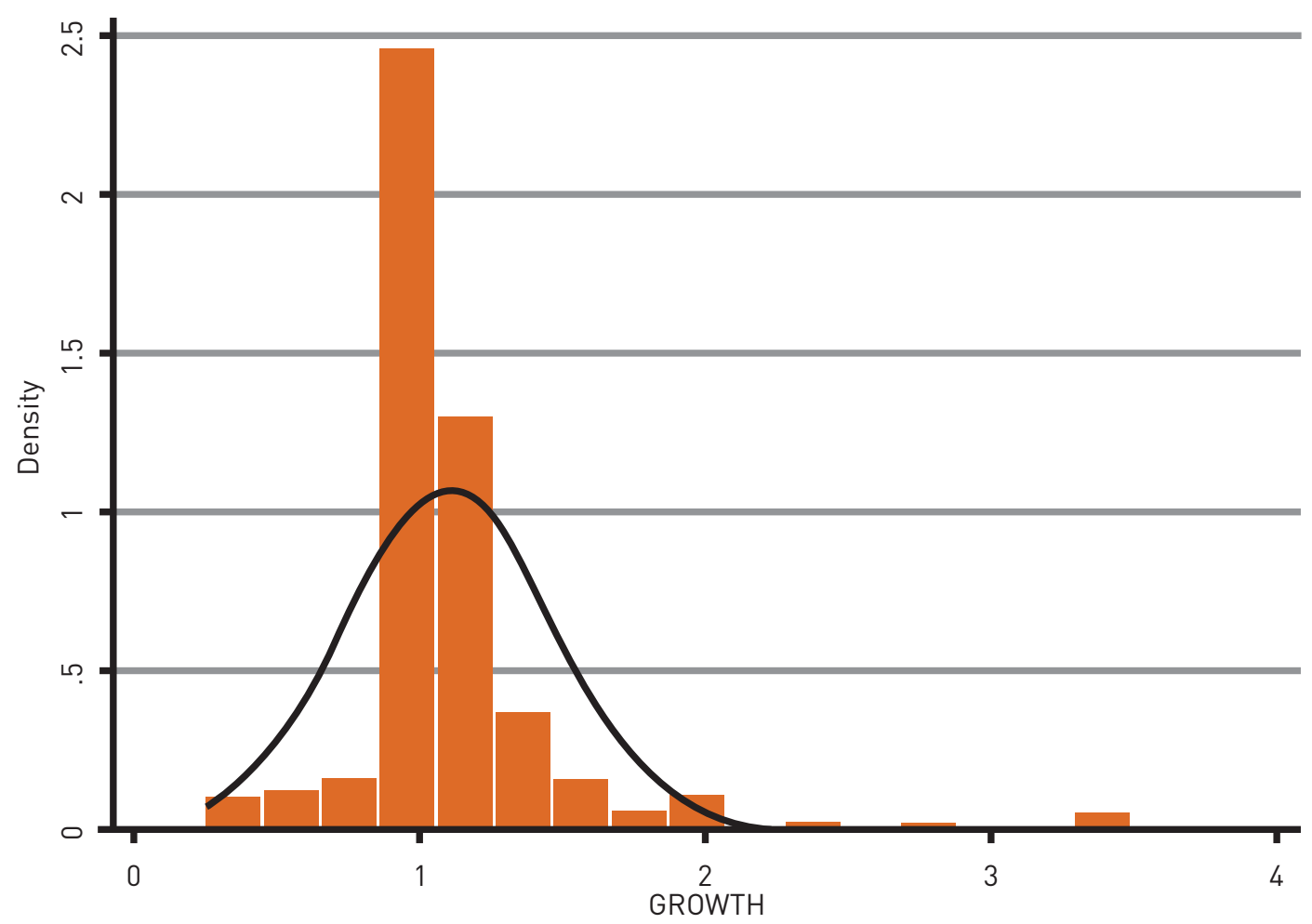

WACC probability distribution

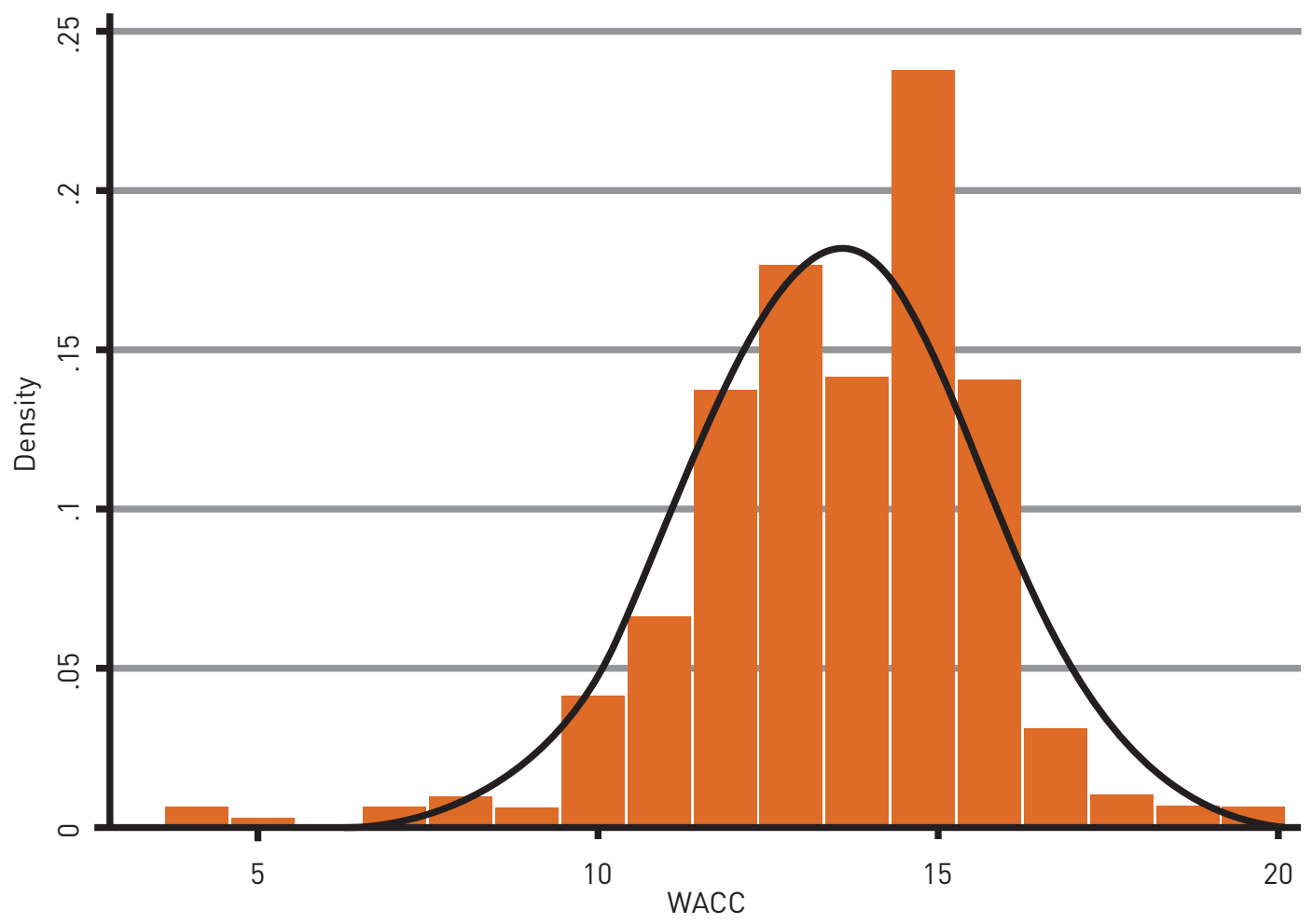




\section{LIQ probability distribution}

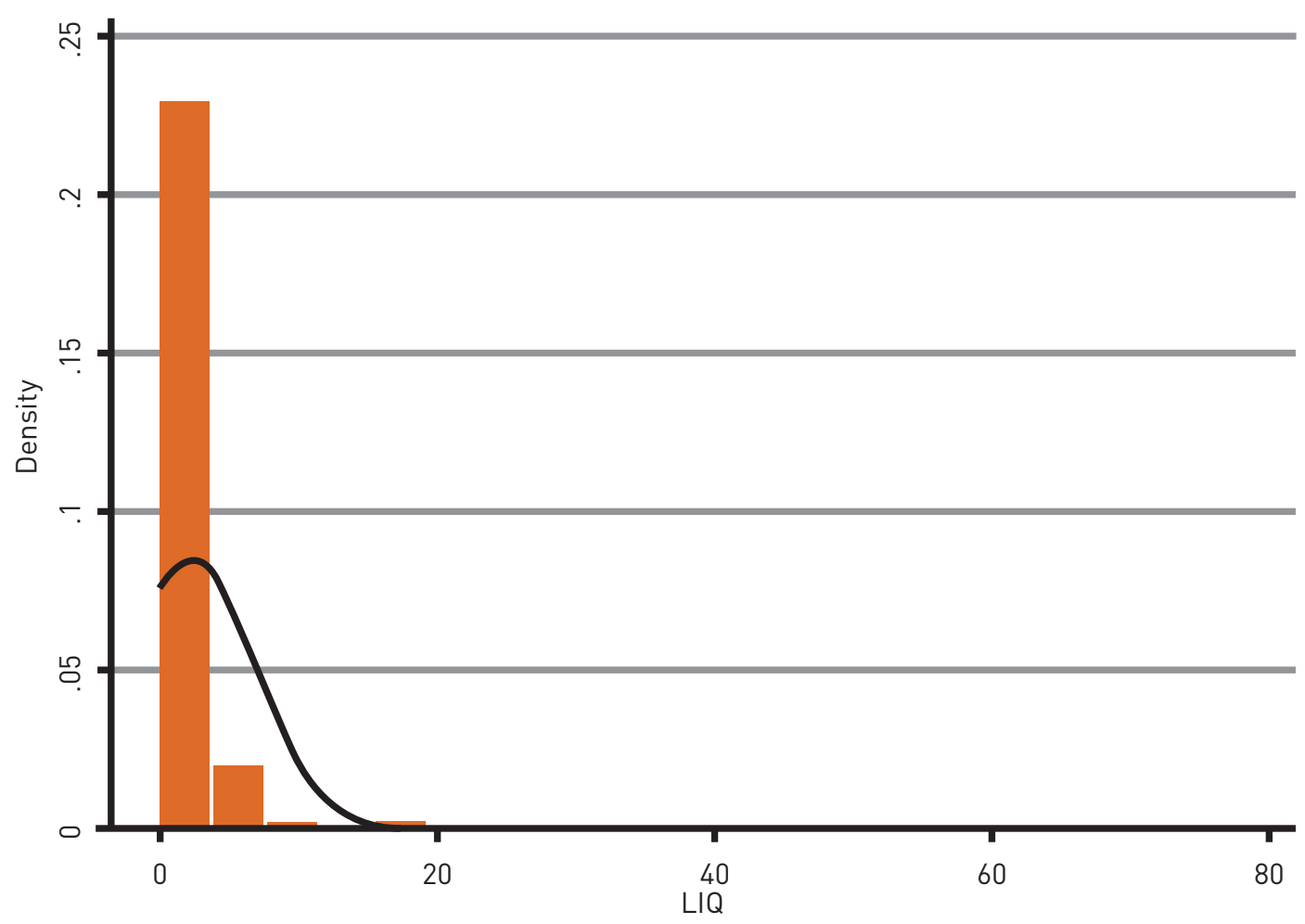

\section{EFF probability distribution}

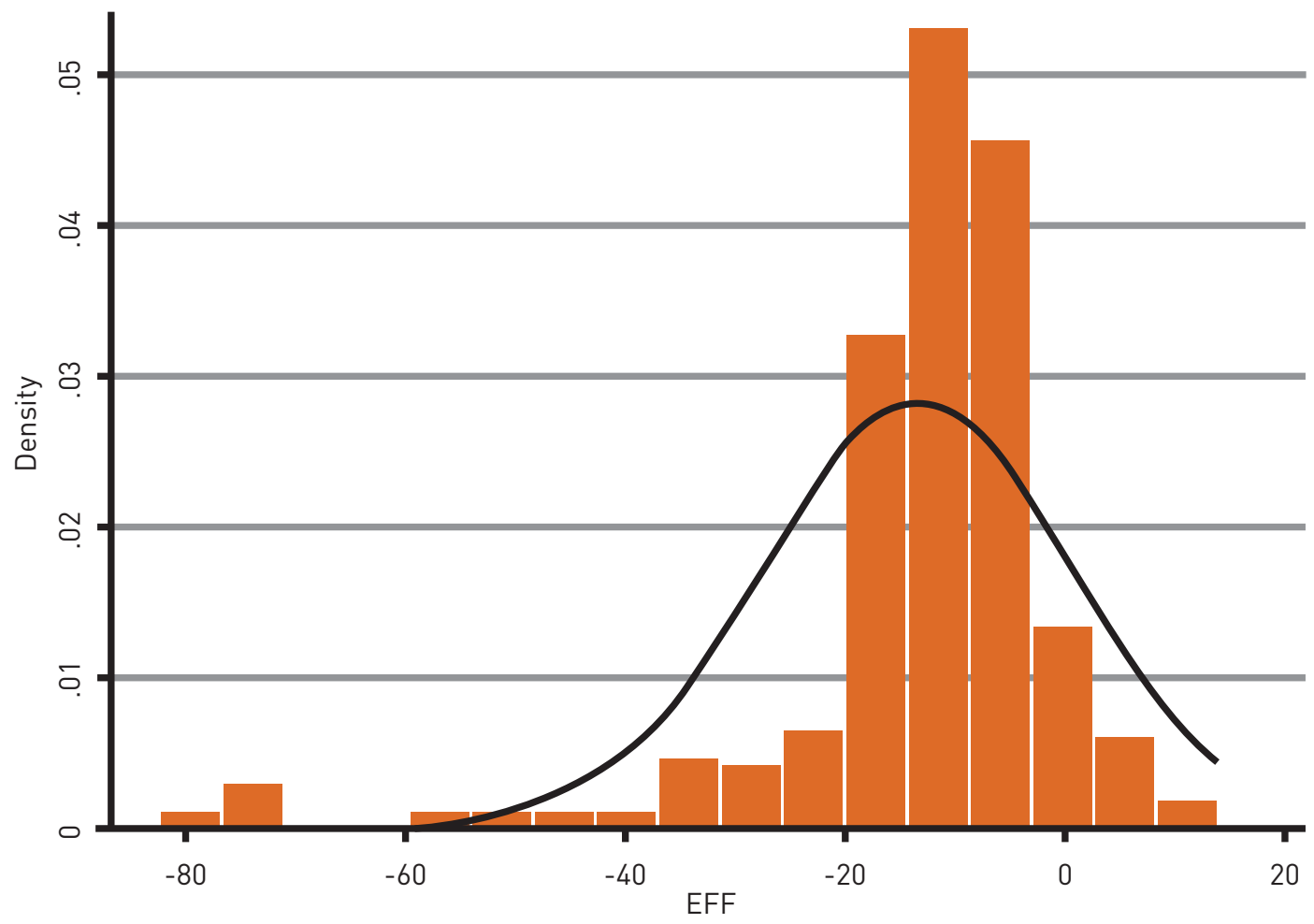

Contribution of the authors: the authors contributed equally to this article.

The authors declare no conflicts of interests.

The article was submitted 06.07.2021; approved after reviewing 08.08.2021; accepted for publication 14.08.2021. 